\title{
Assessment of Potential Toxic Metals in a Ramsar Wetland, Central Mexico and its Self-Depuration through Eichhornia crassipes
}

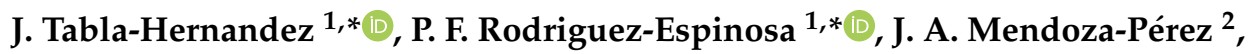 \\ E. Sánchez-Ortíz ${ }^{3}$ (D) E. Martinez-Tavera ${ }^{4}$ and A. G. Hernandez-Ramirez ${ }^{1}$ \\ 1 Instituto Politécnico Nacional-Centro Interdisciplinario de Investigaciones y Estudios sobre Medio \\ Ambiente y Desarrollo (IPN-CIIEMAD), Calle 30 de junio de 1520, Barrio de la Laguna Ticomán, \\ Alcaldía Gustavo A Madero C.P. 07340, CDMX, Mexico; gabo_heera@hotmail.com \\ 2 Instituto Politécnico Nacional-Escuela Nacional de Ciencias Biológicas (IPN-ENCB), Av. Wilfrido \\ Massieu SN, San Bartolo Atepehuacan, U.P. Adolfo López Mateos, Gustavo A. Madero C.P. 07738, \\ CDMX, Mexico; jorgemendozaperez@yahoo.com \\ 3 Instituto Politécnico Nacional—Centro Interdisciplinario de Investigación para el Desarrollo Integral \\ Regional Unidad Durango (IPN-CIIDIR, Unidad Durango), Calle Sigma \#119, Fracc. 20 de Noviembre II, \\ Durango Dgo. C.P. 34220, Mexico; eduardo.sanchezortiz@gmail.com \\ 4 Universidad Popular Autónoma del Estado de Puebla (UPAEP), 17 Sur No. 901 Barrio de Santiago, \\ C.P. 72410 Puebla, Pue., Mexico; estefmtzt@hotmail.com \\ * Correspondence: jacobotabla@hotmail.com (J.T.-H.); pedrof44@hotmail.com (P.F.R.-E.); \\ Tel.: +52-(55)-57296000 (ext. 52711) (J.T.-H.)
}

Received: 7 May 2019; Accepted: 12 June 2019; Published: 14 June 2019

\begin{abstract}
The Valsequillo reservoir is a Ramsar wetland due to its importance as a point of convergence of migratory waterfowl. It is located in Central Mexico and is currently endangered by the constant spill of municipal and industrial discharges from Puebla city. On this context, we evaluated thirteen potential toxic metals (PTMs) in water, Water hyacinth (E. crassipes) plants and sediments at this site. A combined number of 31 samples were collected from the study area. The degree/extent of metal contamination in sediments was assessed through different geochemical indexes, namely: Geoaccumulation index $\left(I_{g e o}\right)$, Enrichment Factor (EF) and Potential Ecological Risk Index (PERI). The ability of Water hyacinth plants residues as a phytodepurator in the Ramsar site was tested in terms of the bioaccumulation factor (BF) and the translocation factor (TF). The results concerning sediments showed that $\mathrm{Pb}, \mathrm{Cu}$ and $\mathrm{Hg}$ pose a threat to the aquatic environment since $I_{g e o}$ and $\mathrm{EF}$ indicate sediments ranging from moderately contaminated to contaminated. Moreover, PERI pointed out $\mathrm{Hg}$ as the main contributor to the ecological risk in sediments, especially in the part of the reservoir covered by E. crassipes. Water hyacinth plants displayed good capacity to absorb PTMs from the water, since the content of $\mathrm{Co}, \mathrm{Zn}, \mathrm{As}, \mathrm{Ni}, \mathrm{Cu}$, $\mathrm{Pb}, \mathrm{Ti}, \mathrm{Cr}, \mathrm{Ba}$, Mo and $\mathrm{V}$ in the total plant was (all values in $\mathrm{mg} / \mathrm{kg}$ of dry weight) $21 \pm 9,408 \pm 300$, $12 \pm 6,93 \pm 21,93 \pm 69,53 \pm 29,1067 \pm 643,78 \pm 55,362 \pm 39,14 \pm 0.6$ and $96 \pm 35$, respectively. Metal content in sediments resembles to that of E. crassipes; especially in the roots, suggesting a constant deposition of plants at the bottom of the reservoir, which contributes to the eutrophication of the water. The present work encourages the need for a sustainable management of Water hyacinth plants in the Ramsar site, since they represent a plague and a natural phyto-depurator at the same time.
\end{abstract}

Keywords: ecological risk; enrichment factor; phytoremediation; potential toxic metals; translocation factor; bioaccumulation factor; Ramsar site; surface sediments 


\section{Introduction}

Ramsar sites are sites that involve wetlands which are considered to be of great importance due to the ecosystem services that they provide [1]. These sites are under pronounced pressure owing to the presence of pollutants such as PTMs. Because of their non-biodegradable nature, persistence, capacity for bioaccumulation, and biomagnification in food chains, these metals are potentially hazardous to aquatic fauna and flora and thus to human life [2]. Toxic metals are released to the environment, mainly because of the natural weathering of the rocks and volcanic activity and because of human activities such as agriculture, mining, and industry [3,4]. The metals can be classified into four large groups according to their degree of toxicity reported in humans: (1) major toxic metals, (2) minor toxic metals, (3) essential metals and (4) metals related to medical therapy [5]. However, all metals can be potentially toxic at some point [6].

The rivers transport suspended particles towards lakes or reservoirs, which may subsequently be deposited into sediments; this is an important route for toxic metals to the reservoirs, as they are frequently attached to suspended particles [2] (Kamari et al., 2017) and they can remain there for a considerable time [7]. Moreover, in the surface sediments there are large environmental variations that can quickly alter different factors such as $\mathrm{pH}$, and temperature. As a consequence, bioturbation (suspension) can also be released from the surface sediments to the water column, which negatively affects the quality of the water $[4,8]$. The measurement of PTMs in sediments is essential when assessing the potential environmental and ecotoxicological impacts [9]. However, the analysis of PTMs in surface sediments only determines the extent, distribution and possible origin [10]. Therefore, different indexes and factors such as Enrichment Factor (EF), Geoaccumulation Index $\left(I_{g e o}\right)$ and Potential Ecological Risk Index (PERI) have been developed and utilized all around the world with the aim of evaluating the possible risk associated with the presence of PTMs in sediments [11-13]. These indexes are useful in delineating the PTMs source as an anthropogenic and naturally occurring source, in measuring the degree of contamination in surface sediments and in evaluating the potential risk of individual PTM to the surrounding ecosystem $[7,14,15]$.

Phytoremediation has been utilized as a natural technique to purify wastewaters due to its environmental friendliness, cost effectiveness and the possibility to extract the PTM absorbed by the plants by means of the harvesting [16-18]. However, phytoremediation techniques are generally implemented in constructed wetlands to treat wastewater before they are subsequently used or even discharged into the water bodies [19-21]. Notwithstanding this, if wastewater-containing PTMs are directly discharged into the rivers or lakes, little can be done to eliminate PTMs from these sites.

In spite of the above, there are some works in which self-purification processes are reported within water bodies with the presence of aquatic plants. Shao-wei studied the self-depuration process in the "Erh-Chung" wetlands in Taipei city, in which domestic and industrial wastewaters, and seepage water from landfills, have caused serious pollution problems. However, Water hyacinth plants covering up to seventy percent of the wetlands acted as a biofilter, accumulating up to 24, 542, 2162, 2617, and $1346 \mathrm{mg} / \mathrm{m}^{2}$ of $\mathrm{Cd}, \mathrm{Pb}, \mathrm{Cu}, \mathrm{Zn}$ and $\mathrm{Ni}$, respectively. On the other hand, Chunkao et al. [22] proved that Water hyacinth plants were able to accumulate PTMs such as: (all values in mg/Kg d.w.) Zn (0.04), $\mathrm{Pb}$ (0.008), $\mathrm{Cu}(0.03)$ and $\mathrm{Cd}(0.19)$ in the "Bueng Makkasan" pond of Bangkok City.

Water hyacinth plant is one of the most commonly used aquatic plants for phytoremediation purposes as it is a productive plant and can tolerate considerable variation in nutrients, temperatures, and $\mathrm{pH}$ levels $[21,23,24]$. Some authors have demonstrated that Water hyacinth plants can be efficient in the removal of PTM from contaminated natural water bodies $[16,22,25]$. This process often occurs without harmful effects on the plant since much of the PTMs is accumulated by adsorption to anionic sites in the cell walls [17]. As a result, the PTMs do not enter the living part of the plant (such as the cell walls) and they can remain stored in the plants for a considerable time [26]. To evaluate the performance of Water hyacinth plants in the water depuration, some authors have proposed factors such as the Translocation factor (TF) and Bioaccumulation factor (BF) [17]. The importance of studying 
the depuration process through the BF and TF relies on the possibility to determine whether the plant has potential for using it in situ as a water depurator or not $[27,28]$.

Although there are some works related to natural wetlands in which results regarding the concentrations of PTMs are presented, only a few of them evaluated the effect of self-purification in a global way. Valsequillo reservoir located in Puebla City was titled as a Ramsar site (No. 2027) in 2012 as it sustains important fauna and flora—especially Water hyacinth plants-that occupy around $50 \%$ of the total area. It has been the receptacle of municipal and industrial wastes for the past few decades that gravely affected the water quality [29]. Therefore, the present work aims to evaluate the Valsequillo Ramsar as a biofiltration system, which carries out a self-depuration process though the action of Water hyacinth plants covering the reservoir. For that purpose, the concentration of thirteen PTMs (As, $\mathrm{Ba}, \mathrm{Cd}, \mathrm{Co}, \mathrm{Cr}, \mathrm{Cu}, \mathrm{Hg}, \mathrm{Mo}, \mathrm{Ni}, \mathrm{Pb}, \mathrm{Ti}, \mathrm{V}$ and $\mathrm{Zn}$ ) in water, Water hyacinth plants (E crassipes) and sediments were determined. In addition, the indices and factors mentioned above were also calculated to determine both the quality of the sediments and the ability of the Water hyacinth plants to absorb and transfer PTMs to the different parts of the plant.

\section{Materials and Methods}

\subsection{Study Area}

Valsequillo reservoir lying between $18^{\circ} 55^{\prime} 12^{\prime \prime} \mathrm{N} ; 98^{\circ} 11^{\prime} 24^{\prime \prime} \mathrm{W}$ in the state of Puebla, Central México was built in 1946 with a total surface of 3153.9 hectares [30], a breadth ranging from 2 to $7 \mathrm{~km}$, a length of $15 \mathrm{~km}$ and a depth of 2-40 $\mathrm{m}$ [31]. The average flow entering the Valsequillo reservoir during the dry season was calculated based on the preliminary values reported by CONAGUA [30]. They were found to be $5.84 \mathrm{~m}^{3} / \mathrm{s} \pm 2.7\left(\mathrm{n}=38\right.$ years) and $0.24 \pm 0.12 \mathrm{~m}^{3} / \mathrm{s}(\mathrm{n}=8$ years) for the Atoyac River and Alseseca river, respectively. About $88 \%$ of the water in the Alseseca River is in fact wastewater (industrial and municipal discharges), while the Atoyac River contains only $26 \%$ wastewater and the rest is surface water from natural runoff [32]. The main sources of PTMs in the basin are attributed to natural and anthropogenic activities. The automotive industries discard wastes that contain $\mathrm{Cr}, \mathrm{Ti}, \mathrm{Cd}, \mathrm{Pb}, \mathrm{Zn}$, $\mathrm{V}$ and $\mathrm{Ni}$ in both rivers. Mo and $\mathrm{Hg}$ are frequently found in the wastewaters of the textile industry. $\mathrm{Ni}, \mathrm{V}$ and Co have a significant presence due to pesticides used in agricultural activities. As, Co and Ba are mainly consequences of natural contributions. At the time of its construction, the reservoir had a storage capacity of 404.5 million $\mathrm{m}^{3}$, due to the constant spill of wastes. To date, the reservoir has lost around 56\% of its initial capacity [33]. The months of March, April and May represent the dry season [31]. Therefore, in the present work the sampling campaign was carried out on 26 April 2017, since in this month the cumulative effect of the dry season is observed.

\subsection{Geological Settings}

Valsequillo reservoir located in the High Atoyac basin of Puebla situated in the Trans Mexican Volcanic Belt is surrounded by mountain ridges of Upper Cretaceous limestone and Neogene-Quaternary stratovolcanoes, namely, Iztaccíhuatl (extinct), Popocatépetl (active) and Malinche (dormant). The northern limits of the High Atoyac basin are characterized with Pliocene lacustrine deposits composed of shales and sandstones. Paleozoic metamorphic rocks of the Acatlan complex and Mesozoic terrigenous and calcareous rocks form the basement of this basin [34]. The deposits also include thin layers of volcanic ash, rhyolitic, and basaltic with pumice lapilli. The basin contains volcanic tuffs lahars, lava flows, cinder cones, lacustrine fluvial deposits, and reworked glacial-fluvial materials. The Valsequillo basin is underlined by the bedrock of Balsas group constituting coarse Cretaceous limestone conglomerate cemented together by a matrix of red mudstone [35]. Along the shores of the Valsequillo dam, fluvial, lacustrine, tephras and volcaniclastic deposits are exposed, with fossil remains recovered from the Valsequillo gravels [36]. 


\subsection{Water}

\subsubsection{Collection of Water Samples}

When selecting the sampling points, the inlet and outlet of the system as well as several intermediate points along the Valsequillo reservoir were taken into account. Fourteen sampling points of water were selected, including two in Atoyac River, two in Alseseca River and ten in Valsequillo Reservoir (Figure 1). Due to the Valsequillo reservoir being a flooded river valley, it has different depths of water, which depend on the location; at the time of sampling the maximum depths were the following (all values in meters): ATO01 ( 1.4), ATO02 ( 1.9), ALSE01 (0.5), ALSE02 (1.0), VAL01 (1.7), VAL02 (3.4), VAL03 (8.7), VAL04 (8.3), VAL05 (9.3), VAL06 (9.5), VAL07 (20), VAL08 (19.8) VAL09 (9.2), VAL10 (15).

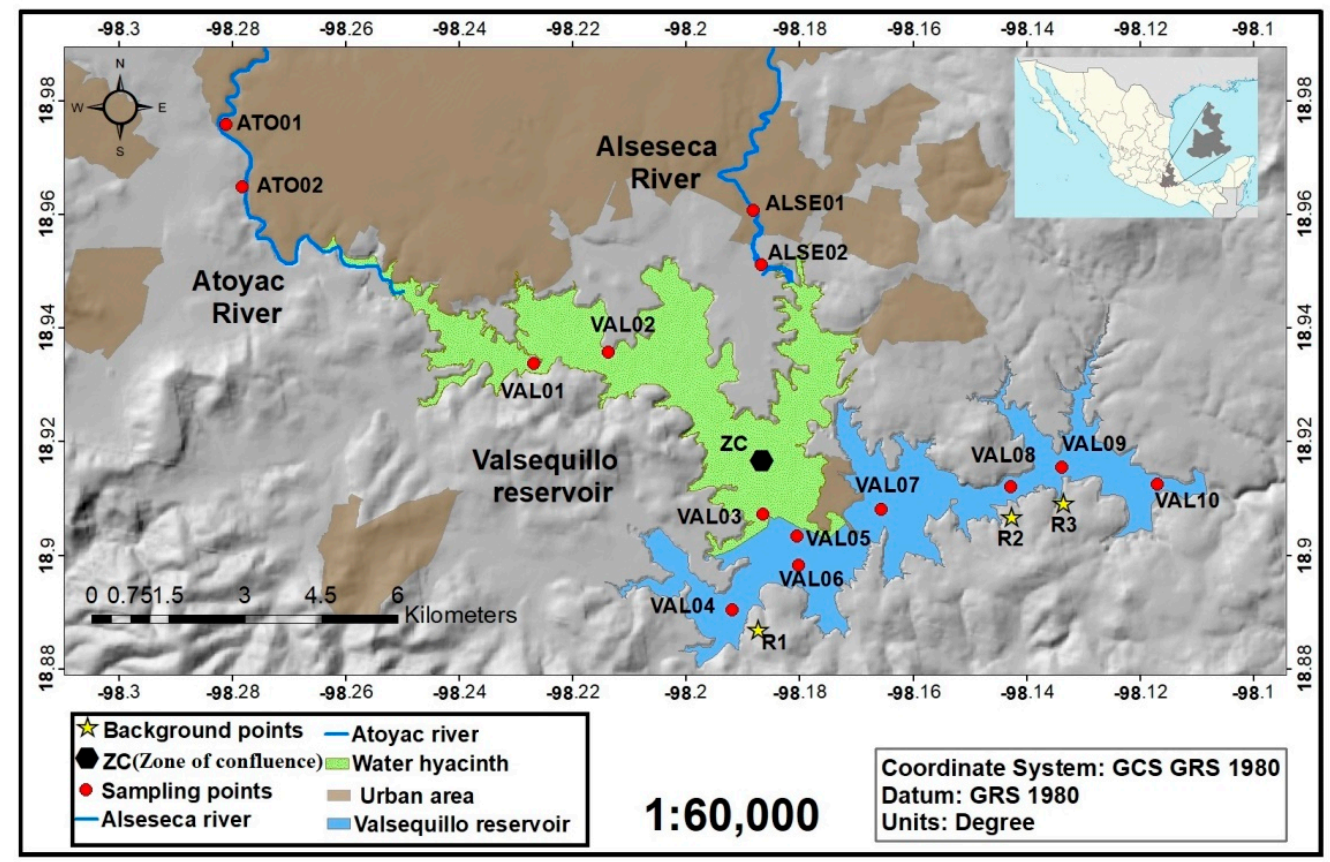

Figure 1. Sampling points in Ramsar site (Valsequillo reservoir) in Puebla, central Mexico.

Water samples were collected at a depth of $20 \mathrm{~cm}$ in $50 \mathrm{~mL}$ polypropylene bottles and were preserved at $\mathrm{pH} 2$ with nitric acid (Ultrex ${ }^{\circledR}$ II reagent) and a temperature $<4{ }^{\circ} \mathrm{C}$. Later they were transported to Activation Laboratories Ltd. (AcLabs) in Ancaster, Ontario, Canada (ISO 17025 accredited and/or certified to 9001:2008). The water samples were analyzed by using an inductively coupled plasma mass spectrometry (ICP-MS) Ultramass 700 (Varian Inc., Palo Alto, CA, USA,) in order to determine the PTM levels. The detection limits of the method were as follow (all values in $\mu \mathrm{g} / \mathrm{L}$ ): As (0.03), Ba (0.1), Cd (0.01), Co (0.005), Cr (0.5), Cu (0.2), Hg (0.2), Mo (0.1), Ni (0.3), Pb (0.01), Ti (0.1), $\mathrm{V}(0.1)$ and $\mathrm{Zn}(0.5)$.

In addition, physicochemical parameters, such as Dissolved oxygen (DO), Hydrogen potential $(\mathrm{pH})$, Electric conductivity (EC), Redox potential (ORP), Temperature (Temp) and Turbidity (Turb) were assessed in situ along each sampling point by using a HACH equipment (Model no: 2100Q \& HQ40D, HACH, Loveland, CO, USA). The accuracy of the parameters was $\pm 0.3^{\circ} \mathrm{C}$ for temperature, \pm 0.02 for $\mathrm{pH}, \pm 0.03 \mathrm{mg} / \mathrm{L}$ for $\mathrm{DO}$ and $\pm 1.5 \mu \mathrm{S} / \mathrm{cm}$ for conductivity.

\subsubsection{Efficiency of the Removal of Potential Toxic Metals from Water}

In the present work, we conceived a biofiltration system on which along with the absorption of PTMs by Water hyacinth, several processes occur which lead to the removal of PTMs from the water. The simplified biofiltration system (coverage of Water hyacinth plants on Valsequillo reservoir) is comprised by two inlets (Atoyac River and Alseseca River), three intermediate points (VAL01, 
VAL02 and VAL03), a zone of confluence (ZC) between VAL02 and Alseseca River and finally an outlet (Figure 2). Due to the difficulty in accessing the part of the reservoir between the sampling point ALSE02 and VAL03, those points were not considered in the simplified biofiltration system. However, it must be taken into account that the entries to the system through the rivers (sampling points ATO02 and ALSE02) and the outlet of the system (VAL03-VAL10), are the most important for the dimensioning proposed here.

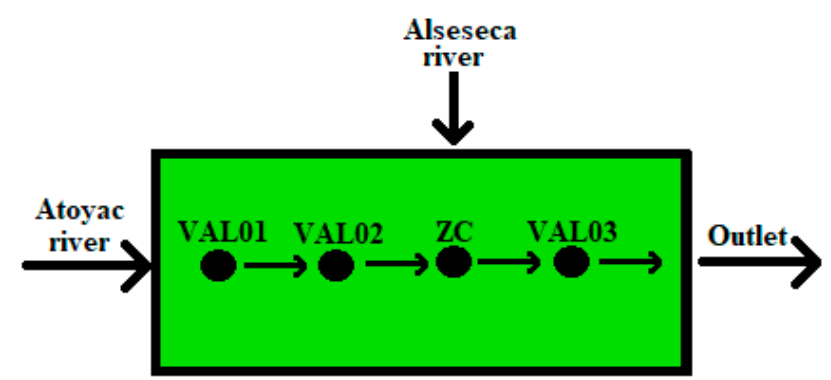

Figure 2. Simplification of the biofiltration system. ZC = zone of confluence. VAL01, VAL02 and VAL03 are sampling points along the Valsequillo reservoir.

For each sampling point, the removal efficiency was calculated using the Equation (1)

$$
R E=\frac{C_{I}-C_{S P}}{C_{I}}
$$

where:

$R E=$ Removal efficiency

$C_{I}=$ Potential toxic metal concentration at the inlet

$C_{S P}=$ Potential toxic metal concentration at each sampling point

For sampling points VAL01 and VAL02, we considered the inlet $\left(C_{I}\right)$ corresponding to the PTM concentrations in Atoyac River; for sampling points VAL03 and the Outlet, the inlet $\left(C_{I}\right)$ is the point of confluence (ZC) where the flow from VAL02 and Alseseca River converge. ZC is calculated by using the Equation (2) (weighted average).

$$
Z C=\frac{\left(C_{1}\right)\left(W F_{1}\right)+\left(C_{2}\right)\left(W F_{2}\right)}{W F_{1}+W F_{2}}
$$

where:

$\mathrm{ZC}=$ Zone of confluence

$C_{1}=$ Potential toxic metal concentration in Atoyac River

$C_{2}=$ Potential toxic metal concentration in Alseseca River

$W F_{1}=$ Water flow in Atoyac River

$W F_{2}=$ Water flow in Alseseca River

With the aim of setting a single outlet value for the biofiltration system, the average value of all PTMs in the reservoir section free of E. crassipes (RF) was taken (see Figure 1 from VAL04 to VAL10). For this purpose, the coefficient of variation $(\mathrm{CV})$ of the PTMs levels was obtained for all the sampling points located from VAL04 to VAL10 by using Equation (3).

$$
C V=\frac{s}{\bar{m}} \times 100
$$


where:

$C V=$ Coefficient of variation

$\mathrm{S}=$ Standard deviation of potential toxic metal content

$\bar{x}=$ Arithmetic mean of potential toxic metal (VAL04-VAL10)

As CV was lower than $20 \%$, the arithmetic mean $\bar{x}$ of potential toxic metal values from sampling point VAL03 to VAL10 were used as outlets of the system.

\subsection{Water Hyacinth Plants (E. Crassipes)}

\subsubsection{Collection of Water Hyacinth Plants Samples}

Several Water hyacinths samples were collected from the study area and transported to Instituto Politécnico Nacional-Centro Interdisciplinario de Investigaciones y Estudios sobre Medio Ambiente y Desarrollo (IPN_CIIEMAD). Water hyacinths samples were washed three times with Milli-Q deionized water without a subsequent washed with deionized acidified water. According to Newete [28], the acid wash eliminates the portion of the adsorbed contaminants such as PTMs. Therefore, by omitting the acid wash, the adsorbed and absorbed portions of the contaminants remain in the plants for further analysis. Later, Water hyacinths samples were separated into aerial parts (sheets and steams) and submerged parts (rhizomes and roots) using a plastic knife (Figure S1). Areal and submerged parts were dried at $105^{\circ} \mathrm{C}$ during $48 \mathrm{~h}$. Water hyacinth plants parts were mashed, packed and sent to Activation Laboratories Ltd. (AcLabs) in Ancaster, Ontario, Canada. Mashed samples ( $1 \mathrm{~g}$ dry weight) were digested with $5 \mathrm{~mL}$ of $\mathrm{HNO}_{3}, 2 \mathrm{~mL}$ of $\mathrm{HCl}$, and $0.4 \mathrm{~mL} \mathrm{HF}$ (Suprapure) and heated up to $180{ }^{\circ} \mathrm{C}$ by using a microwave (Mars-6, CEM Corporation, Matthews, NC, USA) during 45 min. The PTMs concentrations were determined using an inductively coupled plasma mass spectrometry (ICP-MS) Ultramass 700 (Varian Inc., Palo Alto, CA, USA). The detection limits of the method were as follow (all values in mg/L): As (3.0), Ba (7.0), Cd (0.3), Co (1.0), Cr (1.0), Cu (1.0), Hg (1), Mo (1.0), Ni (1.0), $\mathrm{Pb}$ (3.0), Ti (100), V (2) and Zn (1.0).

\subsubsection{Determination of Bioaccumulation and Translocation Factor}

Bioaccumulation factor $(\mathrm{BF})$ and translocation factor $(\mathrm{TF})$ were calculated according to Equations (4) and (5), respectively [20,37].

$$
\begin{aligned}
& B F=\frac{C S}{C W} \\
& T F=\frac{C A}{C S}
\end{aligned}
$$

where:

$C W=$ Concentration levels of each potential toxic metal in water

$C S=$ Concentration levels of each potential toxic metal in the submerged part of the Water hyacinth

$C A=$ Concentration levels of each PTM in the aerial part of the Water hyacinth

There is not a consensus regarding what the translocation values represent. However for many authors when TF $<0.1$ is considered to be an exclusion plant, a TF between 0.1 and 1 is considered to be tolerant and a TF of $>1$ indicates a hyper-accumulating plant. Ideally, a good phytoextractor should have a TF $>1$. It means that the plant is translocating the pollutant into the aerial part and hence is liberating the roots and rhizomes for more pollutant to be absorbed [1,38-40]. However, Baker [41] proposed an additional category apart from the one mentioned above, that is an "Indicator" category, which is when uptake and transport of metals to the shoots are regulated so that internal concentration reflects external levels. In other words, a plant is an indicator when metal concentration in it increases proportionally with metal concentrations in the external medium. 
In spite of the above, the translocation factor reflects only the ability to transport the metals into the aerial part of the plants. However, the hyperaccumulation property is related to the ability to concentrate metals in their shoots [42].

\subsection{Sediments}

\subsubsection{Collection of Sediments Samples}

A sediment sampler (Van-veen grab Wilco of $20 \mathrm{~kg}$ capacity) was used to procure a total number of 14 surface sediment samples from the study area (2 in Atoyac River, 2 in Alseseca River and 10 in Valsequillo reservoir). The depths to which the sediments were collected are the following (all values in meters): ATO01 (1.4), ATO02 (1.9), ALSE01 (0.5), ALSE02 (1.0), VAL03 (8.7), VAL04 (8.3), VAL05 (9.3), VAL06 (9.5), VAL07 (20), VAL08 (19.8) VAL09 (9.2), VAL10 (15). The sites where sediment samples were collected, correspond to those of water samples. To calculate the geochemical indices, three local reference samples with no significant external influences (mountainous region) were collected (R1-R3) (Figure 1).

The samples were placed in plastic bags by using a plastic spatula and transported to "Centro Interdisciplinario de Investigaciones y Estudios sobre Medio Ambiente y Desarrollo (CIIEMAD-IPN)". They were dried at $75^{\circ} \mathrm{C}$ and sent to Activation Laboratories Ltd. (AcLabs, Ancaster, ON, Canada) for metal analysis. Powdered samples $(1 \mathrm{~g})$ were meshed (size: 200 micrometers) and subjected to total digestion at $260{ }^{\circ} \mathrm{C}$ with $3 \mathrm{~mL}$ of $\mathrm{HCl}, 20 \mathrm{~mL}$ of $\mathrm{HNO}_{3}, 5$ of $\mathrm{HClO}_{4}$ and $10 \mathrm{~mL}$ of HF acids (Suprapure) [43]. Finally, the digestate was analyzed by using an inductively coupled plasma optical emission spectrometry (ICP-OES) Ultramass 715 (Varian Inc., Palo Alto, CA, USA) to determine the metal levels. The detection limits of the method were as follow (all values in $\mathrm{mg} / \mathrm{L}$ ): As (3.0), Ba (7.0), Cd (0.3), Co (1.0), Cr (1.0), Cu (1.0), Hg (1), Mo (1.0), Ni (1.0), Pb (3.0), Ti (100), V (2) and $\mathrm{Zn}(1.0)$. Sample replicates (three times) were done with analytical blanks at regular intervals and Geochemical Reference Standard Materials (SDC-1, DNC-1, GXR-1, GXR-4 and GXR-6) were run concurrently with the samples and the recoveries were between (average) 91.3 and 123\% for PTM.

\subsubsection{Enrichment Factor (EF)}

The EF normalizes the measured metal content with respect to a sample reference metal, such as $\mathrm{Fe}$, Sc or Al [44]. Aluminum being one of the main elements of Earth's crust; it serves as the normalizing element to calculate EFs of PTM and metalloids element [11,44]. In the present work, aluminum was chosen as reference element for geochemical normalization. In addition, aluminum is a major constituent of the fine fraction (i.e., clay and fine silt) of which surface sediments are mainly composed [10,45]. EF was calculated according to Equation (6) [46].

$$
E F=\frac{\left(C_{M} / C_{A l}\right)_{\text {sample }}}{\left(C_{M \text { ref }} / C_{A l ~ r e f}\right)_{\text {Background }}}
$$

where:

$C_{M}=$ is the concentration of a PTM in the sample

$C_{A l}=$ is the concentration of Aluminum in the sample

$C_{M \text { ref }}=$ is the concentration of a PTM in the natural background value

$C_{A l \text { ref }}=$ is the concentration of a Aluminum in the natural background value

Based on standards purpose by some authors $[47,48]$, when $\mathrm{EF}<2$, there is a minimal enrichment and thus those metals may be entirely from crustal materials or natural weathering processes. The EF value in the range of $2 \leq \mathrm{EF} \leq 5$ shows a moderate enrichment and thus indicates that significant portion of metals is provided by sources other than natural weathering processes. The range of 
$5 \leq \mathrm{EF} \leq 10$ reveals a moderately to severe enrichment and finally the range of $10 \leq \mathrm{EF} \leq 25$ point to a severe enrichment.

\subsubsection{Geoaccumulation Index $\left(I_{\text {geo }}\right)$}

The $I_{g e o}$, originally defined by Müller [13] is a quantitative measure of the metals in surface sediments. The index is mainly a single metal approach to calculate metal accumulation in sediment when the concentration of PTM is 1.5 or greater than their lithogenic background values [49]. The $I_{g e o}$ values were calculated using the Equation (7).

$$
I_{\text {geo }}=\log _{2}\left(\frac{C_{n}}{1.5 B_{n}}\right)
$$

where:

$C_{n}=$ Is the PTM concentration in sediment sample

$B_{n}=$ Is the natural background concentration of $\operatorname{PTM} n$

The factor 1.5 is the coefficient variation of the background data due to lithogenic impacts. The $I_{g e o}$ consists of seven major classes proposed by Ali [50] and Kusin [49], where: $I_{\text {geo }} \leq 0$ indicates no contaminated; $0 \leq I_{\text {geo }} \leq 1$ indicates uncontaminated to moderately contaminated; $1 \leq I_{\text {geo }} \leq 2$ indicates moderately contaminated; $2 \leq I_{\text {geo }} \leq 3$ indicates moderately contaminated to contaminated; $3 \leq I_{\text {geo }} \leq 4$ indicates contaminated to strongly contaminated; $4 \leq I_{\text {geo }} \leq 5$ indicates strongly contaminated to extremely contaminated; $I_{\text {geo }} \geq 5$ indicates extremely contaminated.

\subsubsection{Potential Ecological Risk Index (PERI)}

The PERI was developed by Hakanson [12] with the objective of measuring the pollution degre of metals (oids) in sediments [44]. It was proposed as the sum of individual metals (oids) potential risk factors in sediments (monomial potential ecological risk factor). The PERI was originally based on eight parameters, namely the levels of $\mathrm{As}, \mathrm{Cd}, \mathrm{Cr}, \mathrm{Cu}, \mathrm{Hg}, \mathrm{Pb}, \mathrm{PCB}$ and $\mathrm{Zn}$ [2]. However, since its postulation, a few authors have added more metals to the calculation of PERI such as Vanadium (V), Nickel (Ni), Antimony ( $\mathrm{Sb})$ and cobalt $(\mathrm{Co})$ with the aim of making the PERI more precise when including other PTMs $[11,44,49,51]$. In the present work, the PCB value was excluded since it was not assessed. The PERI was calculated using the Equations (8)-(10).

$$
\begin{aligned}
\text { PERI } & =\sum E \\
E & =T C \\
C & =\frac{C_{a}}{C_{b}}
\end{aligned}
$$

where:

$E=$ Monomial potential ecological risk factor

$T=$ Toxic-response factors or toxicity coefficients $(\mathrm{Zn}=1, \mathrm{Cr}=\mathrm{V}=2, \mathrm{Co}=\mathrm{Ni}=\mathrm{Cu}=\mathrm{Pb}=5, \mathrm{As}=10$,

$\mathrm{Cd}=30, \mathrm{Hg}=40$ )

$\mathrm{C}=$ Contamination factor

$C_{a}=$ Concentration of PTM in the sediment sample

$C_{b}=$ Background value of the PTM in sediments (Metal concentrations in sediment samples R1, R2 and R3).

Hakanson [12] established a criterion to determine the degrees of both the monomial potential ecological risk factor and the PERI, namely, low risk $(<150)$, moderate risk $(150 \leq$ PERI $\leq 300)$, considerable risk $(300 \leq \mathrm{PERI} \leq 600)$, high risk (PERI $>600)$. 


\subsection{Statistical Analyses for Metal Content in Three Matrices Studied}

All data groups were checked for normality and variance homogeneity prior to the statistical processing by using Shapiro-Wilk and Levene tests, respectively. In case of acceptance, differences among concentrations of PTM in water, Water hyacinth plants and sediments were determined using one-way analysis of variance (ANOVA). In the case of non-acceptance of normality and variance homogeneity, Kruskal-Wallis test was performed. To identify the source of significant differences between groups, Tukey post hoc tests and Dunn's method with a significance level of $p=0.05$ were carried out for parametric and non-parametric data, respectively. Pearson's correlation index was applied to find possible interactions between the concentrations of PTMs in Water hyacinths collected. Statistical analyses were carried out using Sigma Plot 12.0 (Systat Software Inc., San Jose, CA, USA).

\section{Results and Discussion}

\subsection{Physicochemical Parameters and Potential Toxic Metal (PTMs) in Water}

The physicochemical parameters measured along the sampling point are presented in Table 1. DO concentrations are between 0.25 and $3.52 \mathrm{mg} / \mathrm{L}$. The part of the reservoir covered with Water hyacinth plants (RW) presents the lower values mainly because aquatic plants act as a barrier between the atmosphere and the water, preventing the dissolution of oxygen into the surface water. However, the difference is not statistically significant $(p>0.05)$. It is reasonable to assume this premise but more data is needed to verify this assumption. Temperature is significantly higher in the rivers than in the rest of the reservoir, however, this may be due to the time of the sampling was not the same, being in the morning in rivers (8:00 a.m.) and in the afternoon for the reservoir. The $\mathrm{pH}$ is not significantly different among the different zones studied, probably due to the buffer effect that a high concentration of carbonates coming from natural sources, confers on the reservoir [52]. Moreover, like $\mathrm{pH}$, the ORP is almost constant along the system. Nevertheless, ORP correlates negatively with temperature $(p<0.05)$ mainly because oxygen (the oxidizing agent in the reduction oxide reactions) is reduced at higher temperatures and vice versa.

Table 1. Physicochemical parameters measured along sampling points in the study area.

\begin{tabular}{|c|c|c|c|c|c|c|}
\hline Sampling Point & DO (mg/L) & Temp $\left({ }^{\circ} \mathrm{C}\right)$ & $\mathrm{pH}$ & ORP & Turb (NTU) & $\mathrm{EC}(\mu \mathrm{S} / \mathrm{cm})$ \\
\hline ALSE01 & 2.53 & 22.70 & 8.11 & 143.00 & 138.00 & 2147.20 \\
\hline ALE02 & 2.79 & 23.70 & 6.71 & 135.00 & 135.00 & 1756.20 \\
\hline ATO01 & - & 25.60 & 7.42 & 91.70 & 56.60 & 1187.20 \\
\hline ATO02 & 2.62 & 26.70 & 7.82 & -76.30 & 57.70 & 1167.20 \\
\hline VAL01 & 1.17 & 18.72 & 7.85 & 32.10 & 99.80 & 1271.14 \\
\hline VAL02 & 2.33 & 21.62 & 7.51 & 126.00 & 23.60 & 1096.56 \\
\hline VAL03 & 0.31 & 19.63 & 7.64 & 223.80 & 9.74 & 838.00 \\
\hline VAL04 & 0.79 & 19.12 & 6.81 & 170.30 & 9.10 & 827.00 \\
\hline VAL05 & 2.76 & 21.40 & 7.60 & 149.30 & 8.76 & 837.20 \\
\hline VAL06 & 2.78 & 19.90 & 7.17 & 145.10 & 4.66 & 826.00 \\
\hline VAL07 & 2.25 & 19.91 & 6.89 & 122.10 & 2.90 & 821.00 \\
\hline VAL08 & 0.25 & 20.15 & 7.76 & 150.40 & 1.90 & 816.00 \\
\hline VAL09 & 3.52 & 20.69 & 7.96 & 159.00 & 2.10 & 810.00 \\
\hline VAL10 & 2.30 & 21.97 & 7.66 & 181.90 & 1.27 & 813.00 \\
\hline \multicolumn{7}{|c|}{ Physicochemical Parameters (Mean Values \pm SD) in Water from Different Zones of the Reservoir } \\
\hline Sampling zone & $\mathrm{DO}(\mathrm{mg} / \mathrm{L})$ & Temp $\left({ }^{\circ} \mathrm{C}\right)$ & $\mathrm{pH}$ & $\mathrm{ORP}(\mathrm{mV})$ & Turb (NTU) & $\mathrm{EC}(\mu \mathrm{S} / \mathrm{cm})$ \\
\hline Inlet $^{1}$ & $2.64 \pm 0.13^{a}$ & $24.67 \pm 1.80^{\mathrm{a}}$ & $7.51 \pm 0.60^{a}$ & $73.35 \pm 102.28^{a}$ & $96.83 \pm 45.83^{a-c}$ & $1564.45 \pm 474.86^{\mathrm{a}-\mathrm{c}}$ \\
\hline $\mathrm{RW}^{2}$ & $1.26 \pm 1.01^{\mathrm{a}}$ & $19.98 \pm 1.48^{\mathrm{b}-\mathrm{a}}$ & $7.66 \pm 0.17^{\mathrm{a}}$ & $127.30 \pm 95.85^{\mathrm{a}}$ & $44.38 \pm 48.49^{a}$ & $1069.57 \pm 217.92^{\mathrm{a}}$ \\
\hline $\mathrm{RF}^{3}$ & $2.09 \pm 1.16^{\mathrm{a}}$ & $20.44 \pm 0.97^{\mathrm{c}-\mathrm{a}}$ & $7.40 \pm 0.44^{\mathrm{a}}$ & $154.01 \pm 19.15^{\mathrm{a}}$ & $4.38 \pm 3.28^{\mathrm{c}-\mathrm{a}}$ & $821.46 \pm 9.41^{\mathrm{c}-\mathrm{a}}$ \\
\hline
\end{tabular}

${ }^{1}$ Both rivers, ${ }^{2}$ Valsequillo reservoir with Eichhornia crassipes (RW) and ${ }^{3}$ Valsequillo reservoir free of Eichhornia crassipes (RF). Note: The superscript different letters $(a, b$ and $c)$ indicate a significant difference in levels among different zones of the study area (Tukey's test or Dunn's method when appropriate, $p<0.05$ ).

The most significant results regarding the physicochemical parameters are Turbidity and Electric conductivity, as from the inlet (both rivers) to the outlet of the biofltration system (reservoir covered with Water hyacinth); a decrease of both parameters was registered. In fact, the outlet of the system 
(RF) presents values of both parameters significantly lower than at the inlet of the biofiltration system (both rivers). Moreover, Turbidity and Electric conductivity have a strong positive correlation (0.953) with $p<0.05$ (Table S1), revealing that the biofiltration system is efficient in the removal of suspended and dissolved solids.

With respect to the PTMs results, in order to determine the degree of water contamination in the study area, all concentration values were compared with the local regulation reference values for discharges of wastewater into the surface waters (NOM-001-SEMARNAT-1996, Ley Federal de Derechos Disposiciones Aplicables en Materia de Aguas Nacionales 2015 (LFDMA) and Finally Declaratoria de clasificación de los ríos Atoyac y Xochiac y sus afluentes (DCRAX)). Additionally, as with local regulation, the water results were also compared to the Screening Quick Reference Tables (SQuiRTs) from the National Oceanic and Atmospheric administration of the United States Department of Commerce (NOAA). All PTMs levels were shown to be lower than the permissible limits set by local regulations, except for $\mathrm{Hg}$ and $\mathrm{Ba}$ (Table 2).

In Alseseca River, the mean concentration of Hg exceeded the DCRAX limit, probably due to the constant spill of textile and automotive industrial wastes along Alseseca River. On the other hand, mean concentration of Ba exceeded the limit set by LFDMA in all zones studied, possibly related to the natural enrichment in the geology basin [10]. In regards to the SQuiRTs water values, metal content in the four zones studied were barely above the limits. Moreover, levels of $\mathrm{Hg}$ in the rivers are below limits and in the reservoir are close to the limit. Cadmium levels in the two zones of the reservoir (RW and RF) are below the limit, which may pose a threat to the aquatic biota in the reservoir due to the high toxicity of this element.

With respect to the difference in metal concentrations between the parts of the reservoir covered with E. crassipes (RW) and devoid of E. crassipes (RF), it was observed that mean values of $\mathrm{Zn}$ and Ti are significantly greater in the RW than in RF $(p<0.05)$. This is likely because on the shore of the Valsequillo reservoir, particularly close to the sampling point VAL03, there is a human settlement called San Baltazar Tetela, which discharges their residual waters into the reservoir. This wastewater can contain metals coming from a wide variety of domestic household products, such as toothpaste, cosmetics, batteries, and cleaning materials that contain trace concentrations of these metals [39] and thus enriching the content of these metals in that specific zone. In addition, Water hyacinth plants that cover the Valsequillo reservoir absorb metals from water during the growing period, but as proved by Jackson [53], during senescence, the plant is susceptible to release metals along with the Water hyacinth plants tissues into the surrounding water.

Mean concentration values of $\mathrm{Ni}$ and $\mathrm{V}$ are significantly greater $(p<0.05)$ in rivers (Atoyac and Alseseca) than in the zone of reservoir free of Water hyacinth plants (RF). Thus, one may suppose that within the zone covered by Water hyacinths plants, there is a process of metal removal that is performed mainly by these plants. Moreover, the presence of Water hyacinth plants in this zone might promote the sedimentation process driven mainly by the change of the hydraulic regimen. In addition, the plant's rhizosphere stimulates the growth of the aerobic biofilm which may play an important role in adsorbing PTMs from water [54]. Furthermore, the plants can secrete exudates that contain carbohydrates, amino acids, polysaccharides and flavonoids $[55,56]$, which in turn can act as exogenous chelating agents and thus precipitate PTMs. Consequently, this zone can also be termed as a biofiltration system.

The biofiltration system in Valsequillo reservoir proved to be effective in removing PTMs from water as the total PTMs removal efficiency (from the inlet to the outlet) of $\mathrm{Co}, \mathrm{Zn}, \mathrm{As}, \mathrm{Ni}, \mathrm{Cu}, \mathrm{Pb}$, $\mathrm{Ti}, \mathrm{Cr}, \mathrm{Mo}$ and $\mathrm{V}$ was (all values in \%) 18, 71, 19, 42, 51, 65, 51, 5, 54 and 65, respectively. (Table 3). However, for almost all PTMs, the removal efficiency in the first stages of the biofiltration system (i.e., VAL01, VAL02 and VAL03) was low (for some PTMs were zero \%). The above may indicate that when dying, the Water hyacinth plants could be adding these elements to the system. 
Table 2. Potential toxic metal concentrations (mean values \pm SD) in water and sediments from different zones: Alseseca River, Atoyac River, Valsequillo reservoir with Eichhornia crassipes (RW) and Valsequillo reservoir free of Eichhornia crassipes (RF).

\begin{tabular}{|c|c|c|c|c|c|c|c|c|c|c|c|c|c|}
\hline \multicolumn{14}{|c|}{ Water $(\mu \mathrm{g} / \mathrm{L})$} \\
\hline Sampling Zone & Co & $\mathrm{Zn}$ & As & $\mathrm{Ni}$ & $\mathrm{Cu}$ & $\mathrm{Pb}$ & Ti & $\mathrm{Cr}$ & Ва & Mo & $\mathrm{V}$ & $\mathrm{Hg}$ & $\mathrm{Cd}$ \\
\hline Alseseca R. & 0.6 & 51.1 & 2.2 & 7.6 & 1.7 & 0.2 & 8.5 & 4.2 & 89.3 & 0.8 & 8.0 & 1.5 & 0.1 \\
\hline Atoyac R. & 0.4 & 4.8 & 2.8 & 3.9 & 1.2 & 0.1 & 0.4 & 2.0 & 63.1 & 0.6 & 4.8 & 0.8 & 0.0 \\
\hline $\mathrm{RW}$ & $1.2 \pm 0.8^{\mathrm{a}}$ & $6.9 \pm 2.8^{\mathrm{a}}$ & $3.4 \pm 0.8^{\mathrm{a}}$ & $4.8 \pm 0.7^{\mathrm{a}}$ & $1.7 \pm 0.7^{\mathrm{a}}$ & $0.9 \pm 1.1^{\mathrm{a}}$ & $3.2 \pm 3.1^{\mathrm{a}}$ & $2.0 \pm 0.0^{\mathrm{a}}$ & $78.9 \pm 6.9^{\mathrm{a}}$ & $1.4 \pm 1.1^{\mathrm{a}}$ & $4.7 \pm 1.8^{\mathrm{a}}$ & $0.6 \pm 0.2^{\mathrm{a}}$ & $0.6 \pm 1.0^{\mathrm{a}}$ \\
\hline $\mathrm{RF}$ & $0.8 \pm 1.3^{\mathrm{a}}$ & $2.0 \pm 0.0^{\mathrm{b}}$ & $2.7 \pm 1.5^{\mathrm{a}}$ & $2.8 \pm 1.2^{\mathrm{a}}$ & $0.9 \pm 0.9^{\mathrm{a}}$ & $0.4 \pm 1.0^{\mathrm{a}}$ & $0.4 \pm 0.2^{b}$ & $2.2 \pm 0.6^{\mathrm{a}}$ & $76.8 \pm 4.8^{\mathrm{a}}$ & $0.8 \pm 1.3^{\mathrm{a}}$ & $2.3 \pm 1.4^{a}$ & $0.6 \pm 0.0^{\mathrm{a}}$ & $0.5 \pm 1.3^{\mathrm{a}}$ \\
\hline \multicolumn{14}{|c|}{ Comparison with Permissible Limits of Water Set by Different Local and International Regulation } \\
\hline \multicolumn{14}{|l|}{ Regulation } \\
\hline NOM-001-SEMARNAT-1996 & - & 10000 & 200 & 2000 & 4000 & 500 & - & 1000 & - & - & - & 10 & 200 \\
\hline LFDMA & - & 2000 & 100 & 200 & 200 & 500 & - & 100 & $10^{\#}$ & - & - & - & 10 \\
\hline DCRAX & - & 120 & 50 & 600 & 50 & 30 & - & 50 & - & - & - & 1 & 4 \\
\hline (SQuiRTs) * & 3.0 & 120 & $3.1^{+}$ & 52 & 9 & 2.5 & - & $11^{\wedge}$ & 3.9 & 34 & 19 & 0.77 & 0.25 \\
\hline \multicolumn{14}{|c|}{ Sediments (mg/Kg) } \\
\hline Inlet (both Rivers) & $15.7 \pm 2.7^{\mathrm{a}}$ & $88.7 \pm 16.3^{\mathrm{a}}$ & $3.5 \pm 1.0^{\mathrm{a}}$ & $45.2 \pm 13.2^{\mathrm{a}}$ & $15.5 \pm 3.1^{\mathrm{a}}$ & $18.7 \pm 5.9^{\mathrm{a}}$ & $2675.0 \pm 1081.2^{\mathrm{a}}$ & $61.5 \pm 22.4^{\mathrm{a}}$ & $76.15 \pm 24.6^{\mathrm{a}}$ & $1.0 \pm 0.0^{\mathrm{a}}$ & $63.5 \pm 55.2^{\mathrm{a}}$ & $1.2 \pm 0.5^{\mathrm{a}}$ & $0.35 \pm 0.1^{\mathrm{a}}$ \\
\hline $\mathrm{RW}$ & $18.0 \pm 5.3^{\mathrm{a}}$ & $151.0 \pm 23.4^{\mathrm{a}}$ & $3.0 \pm 0.0^{\mathrm{a}}$ & $68.7 \pm 9.3^{\mathrm{a}}$ & $44.3 \pm 3.1^{\mathrm{b}}$ & $24.3 \pm 2.5^{\mathrm{a}}$ & $5033.3 \pm 568^{\mathrm{b}}$ & $68.7 \pm 6.7^{\mathrm{a}}$ & $79.0 \pm 6.9^{\mathrm{a}}$ & $7.0 \pm 5.2^{\mathrm{a}}$ & $118.3 \pm 22^{\text {b-inlet }}$ & $5.7 \pm 7.2^{\mathrm{a}}$ & $0.5 \pm 0.3^{\mathrm{a}}$ \\
\hline RF & $24.7 \pm 5.4^{\text {b-inlet }}$ & $135.3 \pm 41.9^{\text {a }}$ & $4.3 \pm 2.2^{\mathrm{a}}$ & $71.7 \pm 6.3^{\text {b-inlet }}$ & $44.3 \pm 12.4^{\mathrm{c}}$ & $24.9 \pm 6.4^{\mathrm{a}}$ & $4428.6 \pm 442^{\mathrm{c}}$ & $74.7 \pm 8.6^{\mathrm{a}}$ & $76.8 \pm 4.8^{\mathrm{a}}$ & $12.4 \pm 5.8^{\text {b-inlet }}$ & $92.7 \pm 9.4^{\text {a }}$ & $1.0 \pm 0.0^{\mathrm{a}}$ & $0.5 \pm 0.2^{\mathrm{a}}$ \\
\hline \multicolumn{14}{|c|}{ Comparison with Permissible Limits of Sediments Set by International Regulation } \\
\hline (SQuiRTs) $^{1}$ & 50.0 & 120.0 & 6.0 & 16.0 & 16.0 & 31.0 & - & 26.0 & - & - & - & 0.2 & 0.6 \\
\hline (SQuiRTs) $^{2}$ & - & 98.0 & 10.8 & 19.5 & 28.0 & 37.0 & - & 36.3 & - & - & - & - & 0.6 \\
\hline
\end{tabular}

Note: The superscript different letters (a and b) indicate a significant difference in levels of the particular metal between different zones of the study area (Tukey's test or Dunn's method when appropriate, $p<0.05) ;{ }^{\#}$ Protection to aquatic life; ${ }^{*}$ Chronic values for freshwater; ${ }^{+} \mathrm{As}(\mathrm{V}) ;{ }^{\wedge} \mathrm{Cr}(\mathrm{VI}) ;{ }^{1}$ Guidelines for the protection and management of aquatic sediment quality in Ontario Aug 1993; ${ }^{2}$ EPA 905-R96-008. 
Table 3. Potential toxic metal removal efficiency in the biofiltration system. VAL01, VAL02 and VAL03 are sampling points along the Valsequillo reservoir.

\begin{tabular}{|c|c|c|c|c|c|c|c|c|c|c|c|}
\hline \multirow{2}{*}{ Sampling Point } & \multicolumn{11}{|c|}{ Removal Efficiency (Percentage) } \\
\hline & $\mathbf{B a}$ & $\mathrm{Ni}$ & $\mathrm{Zn}$ & As & $\mathbf{V}$ & Co & $\mathrm{Cu}$ & $\mathrm{Pb}$ & Mo & $\mathrm{Cr}$ & $\mathrm{Ti}$ \\
\hline Inlet & $0.0 \%$ & $0.0 \%$ & $0.0 \%$ & $0.0 \%$ & $0.0 \%$ & $0.0 \%$ & $0.0 \%$ & $0.0 \%$ & $0.0 \%$ & $0.0 \%$ & $0.0 \%$ \\
\hline VAL01 & $0.0 \%$ & $0.0 \%$ & $0.0 \%$ & $0.0 \%$ & $0.0 \%$ & $0.0 \%$ & $0.0 \%$ & $0.0 \%$ & $0.0 \%$ & $0.0 \%$ & $0.0 \%$ \\
\hline VAL02 & $0.0 \%$ & $0.0 \%$ & $10.4 \%$ & $0.0 \%$ & $21.6 \%$ & $0.0 \%$ & $25.0 \%$ & $62.5 \%$ & $0.0 \%$ & $0.0 \%$ & $100.0 \%$ \\
\hline VAL03 & $0.0 \%$ & $3.1 \%$ & $6.0 \%$ & $0.0 \%$ & $30.0 \%$ & $0.0 \%$ & $0.0 \%$ & $0.0 \%$ & $0.0 \%$ & $5.1 \%$ & $74.7 \%$ \\
\hline Outlet & $0.0 \%$ & $41.8 \%$ & $71.5 \%$ & $19.2 \%$ & $65.3 \%$ & $18.5 \%$ & $51.0 \%$ & $65.2 \%$ & $54.3 \%$ & $5.1 \%$ & $51.4 \%$ \\
\hline
\end{tabular}

Therefore, one may hypothesize that within the biofiltration system, exists a dynamic equilibrium in which bioaccumulation and release of PTMs by Water hyacinth plants is present at the same time. To test the above hypothesis, PTM content in Water hyacinth plants and sediments were measured and the results are presented below.

\subsection{Potential Toxic Metal in Water Hyacinth Plants}

Mean concentration values are reported in Table 4. Levels of $\mathrm{Hg}$ in Water hyacinth plants were below the detection limits. Meanwhile, Cd content was $0.4 \mathrm{mg} / \mathrm{kg} \mathrm{d} . \mathrm{w}$. just in the submerged part. These results agree with the values reported by Odjegba and Fasidi [18] and Romanova et al. [4] who also observed that among several metals studied, $\mathrm{Hg}$ and $\mathrm{Cd}$ were the less absorbed by the Water hyacinth plants (Table S2). The results also showed that with exception of Ba, most of the PTMs absorbed by Water hyacinth plants were located in the submerged part of the plant (Roots and rhizome.

Table 4. Potential toxic metal (PTM) concentration in different parts of the Water hyacinth.

\begin{tabular}{ccccc}
\hline PTM & Potential Toxic Metal Concentration (mg/kg d.w.) & \multicolumn{2}{c}{ Factors } \\
\hline & Submerged Part & Aerial Part & BF $^{\mathbf{1}}$ & TF $^{\mathbf{2}}$ \\
\hline $\mathrm{Co}$ & $18.6 \pm 8.6^{\mathrm{a}}$ & $2.6 \pm 1.5^{\mathrm{b}}$ & 3628 & 0.15 \\
$\mathrm{Zn}$ & $249.0 \pm 191^{\mathrm{a}}$ & $159.0 \pm 159^{\mathrm{a}}$ & 33569 & 0.66 \\
$\mathrm{As}$ & $9.3 \pm 5.6^{\mathrm{a}}$ & $\mathrm{BDL}$ & 4298 & - \\
$\mathrm{Ni}$ & $69.6 \pm 24.0^{\mathrm{a}}$ & $23.3 \pm 4.1^{\mathrm{a}}$ & 14224 & 0.37 \\
$\mathrm{Cu}$ & $74.6 \pm 63.6^{\mathrm{a}}$ & $18.0 \pm 7.9^{\mathrm{a}}$ & 45149 & 0.33 \\
$\mathrm{~Pb}$ & $37.6 \pm 23.5^{\mathrm{a}}$ & $15.0 \pm 6.1^{\mathrm{a}}$ & - & 0.45 \\
$\mathrm{Ti}$ & $900.0 \pm 624.4^{\mathrm{a}}$ & $166.7 \pm 57.7^{\mathrm{a}}$ & 555147 & 0.26 \\
$\mathrm{Cr}$ & $63.6 \pm 51.6^{\mathrm{a}}$ & $14.3 \pm 5.0^{\mathrm{a}}$ & 31833 & 0.30 \\
$\mathrm{Ba}$ & $86.6 \pm 29.6^{\mathrm{a}}$ & $275.6 \pm 38.6^{\mathrm{b}}$ & 1081 & 3.49 \\
$\mathrm{Mo}$ & $9.6 \pm 1.5^{\mathrm{a}}$ & $4.6 \pm 0.6^{\mathrm{b}}$ & 10022 & 0.49 \\
$\mathrm{~V}$ & $80.6 \pm 32.9^{\mathrm{a}}$ & $15.3 \pm 9.0^{\mathrm{b}}$ & 17184 & 0.21 \\
$\mathrm{Cd}$ & 0.4 & $\mathrm{BDL}$ & - & - \\
$\mathrm{Hg}$ & $\mathrm{BDL}$ & $\mathrm{BDL}$ & - & - \\
\hline
\end{tabular}

\footnotetext{
All values are presented as mean values \pm SD (VAL01, VAL02 and VAL03 $(n=3)$ ); BDL = below detection limit; ${ }^{1}$ Bioaccumulation factor; ${ }^{2}$ Translocation factor. Note: The superscript different letters ( $a$ and $b$ ) indicate a significant difference in levels of the particular metal between different parts of the Water hyacinth plant (Tukey's test or Dunn's method when appropriate, $p<0.05$ ).
}

For Co, Mo and V, the ANOVA analysis showed that the concentration in the submerged part was significantly different with respect to the aerial part of the plant; being as follow: Co $(p=0.034)$, Mo $(p=0.003)$ and V $(p=0.029)$. The Ba showed a different behavior, as the concentration in the aerial part was significantly higher $(p=0.03)$ than in the submerged part of the plant. This may be due mainly to the great mobility of this element within the Water hyacinth plants. It was also found that the concentrations of $\mathrm{Zn}, \mathrm{As}, \mathrm{Ni}, \mathrm{Cu}, \mathrm{Pb}, \mathrm{Ti}$ and $\mathrm{Cr}$ in the submerged part of the plant were higher than in the aerial part. However, the differences were not significant $(p>0.005)$.

For some PTM, there is a positive correlation in which a decrease was observed from the entrance to the exit of the biofiltration system, revealing a pattern that corresponds to a maximum absorption of 
metals by the Water hyacinth plants in the sites closest to the mouths of the rivers Atoyac and Alseseca (Table 5).

This may imply that Water hyacinth plants have undergone an adaptation process to be able to survive to high PTMs levels. These results are in accordance with Romanova et al. [4] who observed a decrease in the absorption of metals (particularly $\mathrm{Pb}$ and $\mathrm{Cd}$ ) from water of a gold mine tailing that was passing through Water hyacinths in the River Ur, Siberia. Moreover, Odjegba and Fasidi [18] reported that concentration of $\mathrm{Cd}, \mathrm{Cr}, \mathrm{Cu}, \mathrm{Hg}, \mathrm{Ni}, \mathrm{Pb}$ and $\mathrm{Zn}$ in the Water hyacinth plants increased with an increase in the metal concentration in the external medium, thus witnessing a link between metal content in the ambient water and the content in the Water hyacinth plants. This may imply that, as stated by Baker [41], Water hyacinth plants act as an indicator more than as a hyperaccumulator in the Valsequillo reservoir.

With exception of some works, the majority of the authors have reported greater concentration of metals in the submerged part of the Water hyacinth plants than in the aerial part (Table S2). Moreover, the roots act as a first barrier for the metal uptake, and thus they become the main filter for the absorption and retention of the metals, consequently the highest metal concentrations in the plant must be inside the root. Furthermore, according to Tejeda et al. [57] the content of PTM in Water hyacinth plants decreases in the following order: Roots $(>50 \%)$, leaves, rhizome $(\sim 10 \%)$, petiole, stem and stolon $(<10 \%)$. This pattern suggest that Water hyacinth plants may adopt a compartmentalization strategy, common in wetland species, which consists in storing the highest levels of PTMs in the submerged part of the Water hyacinth plants (e.g., roots and rhizomes). This is with the aim of protecting the plants against the harmful effects of high levels in leaves, where the photosynthetic processes take place $[58,59]$.

Table 5. Correlation matrix for the concentration of PTMs in Water hyacinth.

\begin{tabular}{|c|c|c|c|c|c|c|c|c|c|c|}
\hline & $\mathrm{Zn}$ & As & $\mathrm{Ni}$ & $\mathrm{Cu}$ & $\mathrm{Pb}$ & Ti & $\mathrm{Cr}$ & $\mathbf{B a}$ & Mo & V \\
\hline Co & - & - & - & - & - & $\underset{* *}{0.998}$ & - & - & - & - \\
\hline $\mathrm{Zn}$ & 1 & - & - & $\underset{* *}{0.999}$ & - & - & $0.994 *$ & - & $\underset{* *}{0.998}$ & 0.994 * \\
\hline As & & 1 & - & - & - & - & - & $\underset{* *}{-0.997}$ & - & - \\
\hline $\mathrm{Ni}$ & & & 1 & - & - & - & - & - & - & - \\
\hline $\mathrm{Cu}$ & & & & 1 & - & - & $\underset{* *}{0.998}$ & - & $\underset{* *}{1.000}$ & $\underset{* *}{0.997}$ \\
\hline $\mathrm{Pb}$ & & & & & 1 & - & - & - & - & - \\
\hline $\mathrm{Ti}$ & & & & & & 1 & $0.993 *$ & - & $0.988^{*}$ & 0.994 * \\
\hline $\mathrm{Cr}$ & & & & & & & 1 & - & $\begin{array}{c}0.999 \\
* *\end{array}$ & $\begin{array}{c}1.000 \\
* *\end{array}$ \\
\hline $\mathrm{Ba}$ & & & & & & & & 1 & - & - \\
\hline Mo & & & & & & & & & 1 & $\begin{array}{c}0.999 \\
* *\end{array}$ \\
\hline $\mathbf{V}$ & & & & & & & & & & 1 \\
\hline
\end{tabular}

* Significantly at $p<0.01$, and ${ }^{* *}$ significantly at $p<0.05$.

Aquatic plants capable of accumulating up to $5000 \mathrm{mg}$ of metals per kilogram of dry plant biomass or those with BCF $>1000$ are considered as hyper-accumulators of PTMs [28,57]. In the present work, the total amount of metals accumulated by Water hyacinth plants was below $5000 \mathrm{mg} / \mathrm{kg}$ d.w. However, with exception of $\mathrm{Cd}$ and $\mathrm{Hg}$, the BFs of all metals were above 1000. Despite being higher than those reported in literature (Table S2), BF values were in accordance with the range $\left(10^{1}-10^{6}\right)$ proposed by Jackson [53]. In addition, the great variety of metals in water of the Valsequillo reservoir stimulates their absorption by the plant, which confirms that bioaccumulation is more effective when there is a combination of metals compared to only one [24]. Therefore, with exception of $\mathrm{Cd}$ and $\mathrm{Hg}$, 
we considered the Water hyacinth plants present in Valsequillo reservoir as an indicator but it can also be considered as hyper-accumulator of all metals studied.

From all metals studied, $\mathrm{Zn}$ presented the highest translocation from the submerged part to the aerial part of the plant. These results were in accordance with reported by Aurangzed et al. [60] who registered high TF in young Water hyacinth plants used as removal agent for a steel foundry effluents (Table S2). This is probably due to the need that the plant has for this metal; although $\mathrm{Zn}$ is potentially toxic, it is also an essential element for the plant [5] which participates in: formation of chlorophyll, conversion of starches to sugars and formation of the auxins (hormones that favor the growth of stems) [2]. Among all PTMs measured, Co presented the lowest mobility followed by V and Ti. Nevertheless, in spite of the low translocation of Ti, it was greatly accumulated in the submerged part of the plant. These results are similar to the ones obtained by Tejeda et al. [57], who reported that among $\mathrm{Cr}, \mathrm{Cu}, \mathrm{Ti}, \mathrm{Pb}, \mathrm{Zn}$, and $\mathrm{Ni}$, Water hyacinth plants in Lerma River, Mexico absorbed more Ti (325 mg/kg d.w.) (Table S2).

From the perspective of the TF, with exception of $\mathrm{Ba}$, all PTMs studied are between 0 and 1 thereby indicating Water hyacinth plants as a tolerant plant for these metals [40]. In the case of Ba, only $24 \%$ of the total content remained in the submerged part of the plant whilst $76 \%$ passed to the aeriated part of the plant. The high concentrations of Ba could be attributed to the natural contribution coming from barite $\left(\mathrm{BaSO}_{4}\right)$ assemblages of Popocatépetl volcano (active) situated on the western side of the study area, generally hosted in K-feldspars, where Ba substitutes $\mathrm{K}$ in many K-bearing minerals [61]. On the other hand, the anthropogenic contribution of Ba may be related to the automotive industry (widely settled in the basin) [31]. This is in accordance with the high levels of $\mathrm{Ba}$ in the ambient waters, as Ba was the most abundant mineral there (See Section 3.1). Thus, it is reasonable that the Water hyacinth plants in Valsequillo reservoir are well adapted to this element and, therefore, its ability to accumulate and translocate this particular PTM is well developed.

In terms of the simplified biofiltration system, with exception of $\mathrm{Co}$, As and $\mathrm{Ti}$, in all PTMs, an increase of TF from the sampling point VAL01 to VAL03 was observed, whilst a decrease of BF at the same time was registered (Figure 3).

In the present work, a plant damage index was not evaluated, and that's why the explanation of such phenomenon is presented in terms of BF and TFs results. Water hyacinth plants present exhaustion in metal capture from the inlet to outlet of the reservoir. This may be related to the Water hyacinths at sampling point VAL03 that reached a threshold metal concentration value; therefore, it became toxic and, thus, inhibitory for the growth of the plant. From these results, it can be inferred that in order to avoid toxicity, the Water hyacinth plants adopts two mechanisms: (1) The plant releases metals from the root into the aquatic environment [62] and consequently BF decreases and; (2) The plant enhances the mobility of metals from the submerged part to the aerial part with the aim of facilitating metal loss during periodical leaf regeneration [59]. These results are similar to those reported by Odjegba and Fasidi [18], who observed a decrease of metal absorption by Water hyacinth plants along with an increase of concentration in the ambient water.

Another reason why the bioaccumulation factors (BF) decreased from VAL01 to VAL03 could be related to the low concentrations of oxygen at the VAL03 site $(0.31 \mathrm{mg} / \mathrm{L})$. According to Kumari and Tripathi [63] and with Zimmels et al. [64], the aeration in wetlands containing Water hyacinth plants generate better conditions for the plant to absorb contaminants. In other words, the lower the oxygenation, the less efficient the absorption of contaminants and vice versa. As mentioned above, the coverage of the Water hyacinth plants could be preventing the exchange of oxygen between the atmosphere and the surface of the water and therefore, that is the reason why the oxygen in this area (very infested with this plant) is lower and, consequently, why the BF decreases. With respect to $\mathrm{Pb}$ at the sampling point VAL02, it was not possible to calculate the BF because the concentration of $\mathrm{Pb}$ in water were found to be below the detection limit (BDL). The same happened with the As in the sampling site VAL03. 

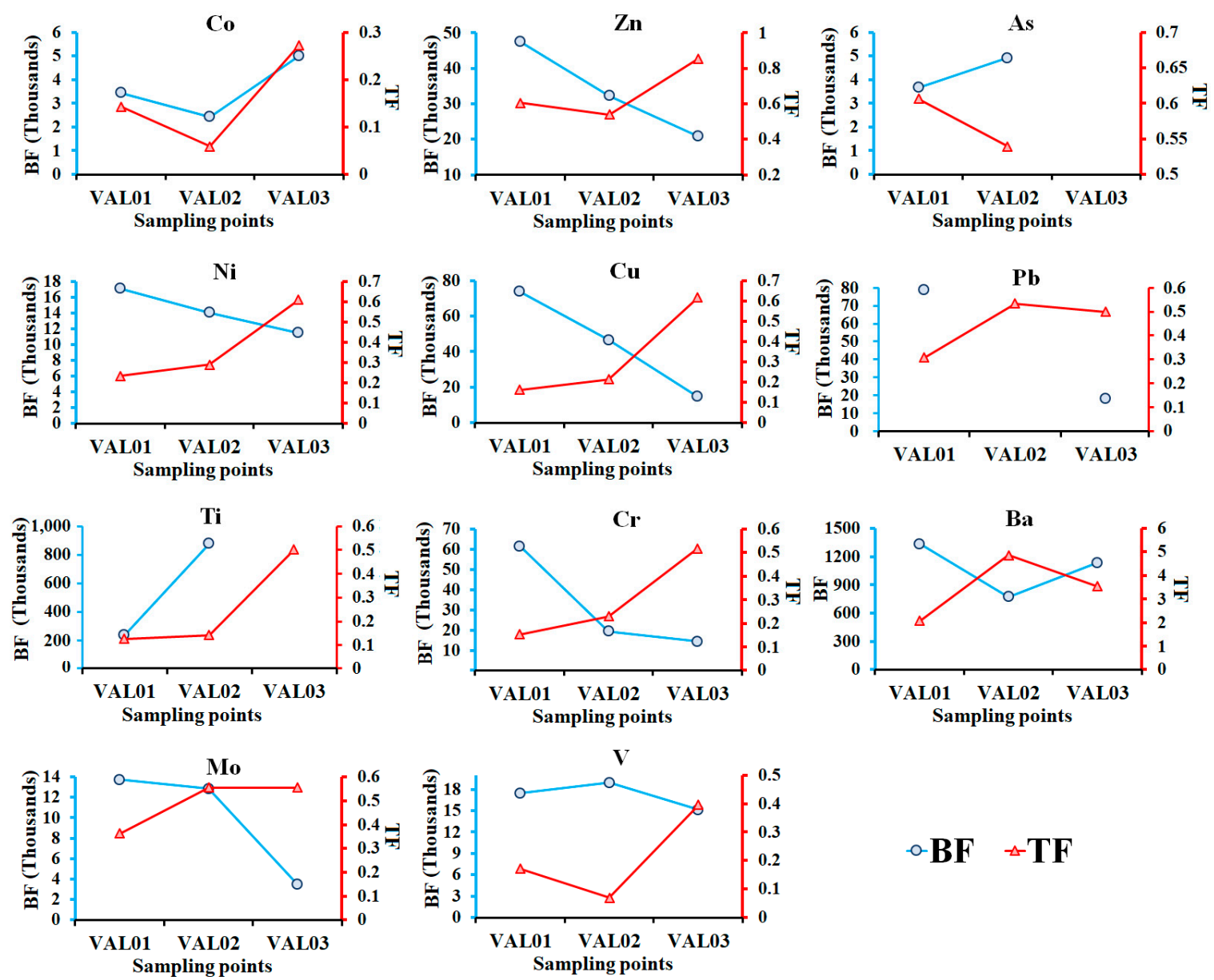

Figure 3. Bioaccumulation factor (BF) and Translocation factor (TF) along sampling points (VAL01, VAL02 and VAL03).

\subsection{Potential Toxic Metal in Sediments}

Metal concentrations in surface sediments along the study area increased from the Reservoir's inlet (rivers) to the reservoir's outlet. PTM levels of $\mathrm{Co}, \mathrm{Ni}, \mathrm{Cu}$, Ti and $\mathrm{Mo}$ in the zone free or E. crassipes $(\mathrm{RF})$ were greater $(p<0.05)$ than in the water of rivers (Table 2$)$. This tendency is opposite to that of water, where metals content in rivers are higher $(p<0.05)$ than in RF, this is particularly true for $\mathrm{Hg}, \mathrm{V}$ and Ni. These results suggest that an intense process of sedimentation of metals takes place in the reservoir driven by Water hyacinth. However, this process can also occur in different forms such as metals attached to the suspended particles, carbonate bound, occluded in iron and/or manganese oxy-hydroxides, bound to organic matter, sulfide bound or by metal chelation [53].

Another important route of metal sedimentation is through the absorption of metals by plants and their subsequent death. This can be corroborated since, there is no significant difference $(p>0.05)$ in the content of metals in sediments and in the Water hyacinth plants for $\mathrm{Co}, \mathrm{Zn}, \mathrm{Ni}, \mathrm{Cu}, \mathrm{Pb}, \mathrm{Cr}$, $\mathrm{Ba}, \mathrm{Mo}$ and V. Moreover, mean metal content in Water hyacinth plants is significantly higher than in sediments for As $(p<0.05)$ (Figure 4$)$. This could imply, as reported by some authors $[54,55]$ that as with $\mathrm{Hg}$ and Selenium (Se) [65], Arsenic (As) in the Water hyacinth plants is undergoing a process of phytovolatilization before it dies.

These results suggest that a major proportion of the surface sediments are composed of dead Water hyacinth. This is in concordance with some studies $[53,66]$ that observed a strong positive correlation between content of metals in Water hyacinth plants and sediments. In particular, roots are the organs that normally correlate most with levels of PTMs in the sediment [59]. 
As discussed previously, the sediments can be a source of contamination to the water column, predominantly $\mathrm{Cd}, \mathrm{Cr}, \mathrm{Cu}, \mathrm{Pb}$ and $\mathrm{Zn}$, particularly when they are attached to organic sediments [58]. Furthermore, Wu et al. [67] reported that finer sediments, as formed by organic matter, tend to have higher metal concentrations and readily wash off into water bodies. This is of particular concern as the Geoaccumulation index $\left(I_{g e o}\right)$ revealed that $\mathrm{Zn}, \mathrm{Cu}, \mathrm{Ti}$, and $\mathrm{V}$ are moderately contaminated in sediments and from the perspective of $\mathrm{Pb}$, sediments are moderately contaminated to contaminated, particularly in the zone of the reservoir free of E. crassipes. Furthermore, with respect to $\mathrm{Hg}$, in RF, sediments fall under the category of contaminated to strongly contaminated (Figure 5a).

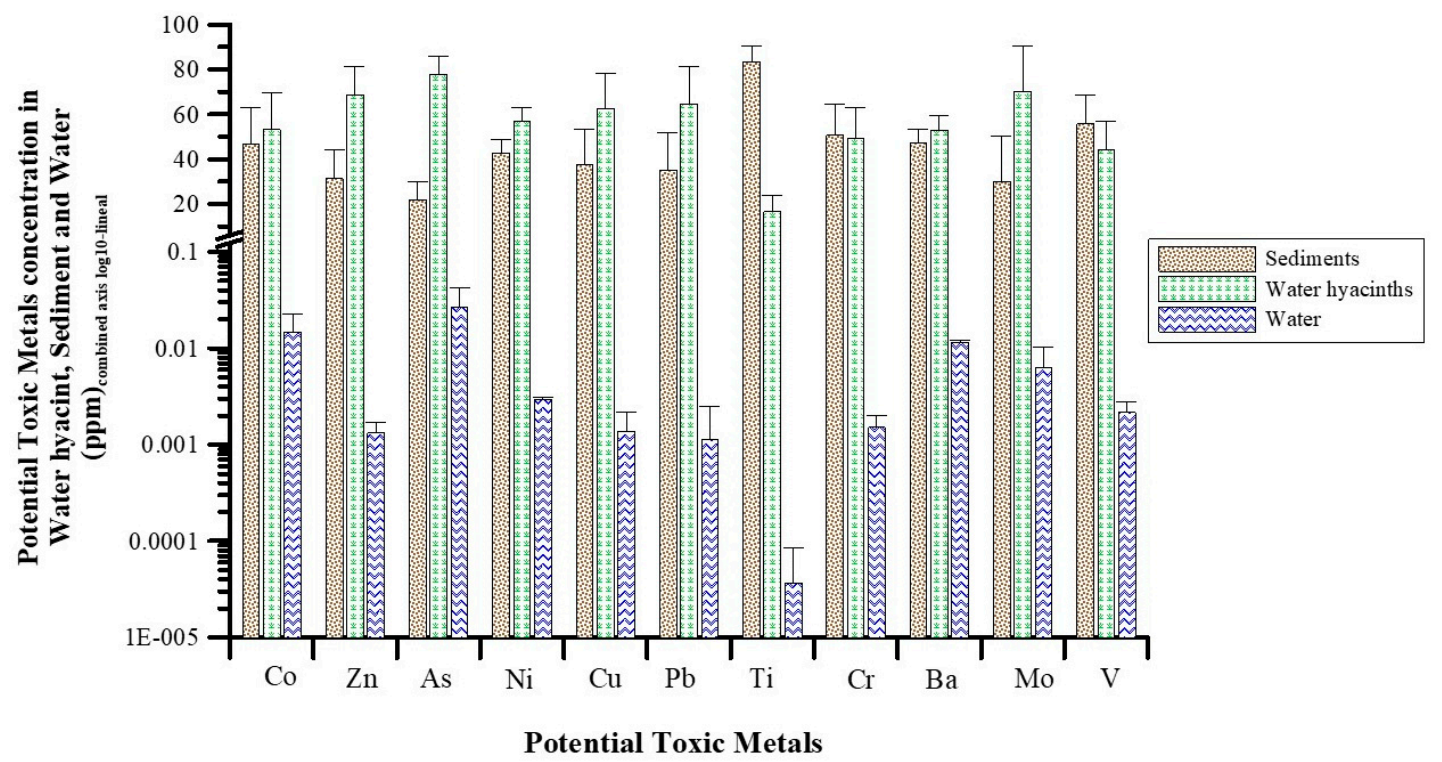

Figure 4. Mean PTMs content of the three sampling points (VAL01, VAL02 and VAL03) in the three matrices studied (Water, Water hyacinth plants and Sediments).

Similar results were presented for Enrichment Factor (EF), since in both the zone of the reservoir with E. crassipes (RW) and the one free of E. crassipes (RF), $\mathrm{Cu}$ and Pb present moderately to severe enrichment. In the case of $\mathrm{Hg}$, only in the zone RW an enrichment was observed. Moreover, except for $\mathrm{V}$ and $\mathrm{Hg}$, an increase of $\mathrm{EF}$ from the inlet (rivers) to the courting of the reservoir (RF) was observed. According to these results, with exception of $\mathrm{Hg}$, the ecological risk in sediments increased in the following order: RF $>$ RW $>$ Alseseca River $\sim$ Atoyac River (Figure $5 b$ ).

The results of EF and $I_{g e o}$ for $\mathrm{Hg}$ are in accordance with the Potential Ecological Risk Index (PERI), as the PERI of RW, RF, Atoyac River and Alseseca River were (all values are dimensionless) 330, 148, 130 and 109, respectively. According to the categories of Hakanson [12], there is a low risk in the sediments of the rivers and in RF. Nevertheless, in RW there is a considerable risk, mainly due to the elevated values of $\mathrm{Hg}$ in that particular zone (Figure $5 \mathrm{c}, \mathrm{d}$ ). These results pointed out the importance of managing the sediments in the reservoir, as they pose a threat to the water quality due to the constant interchange of matter. 

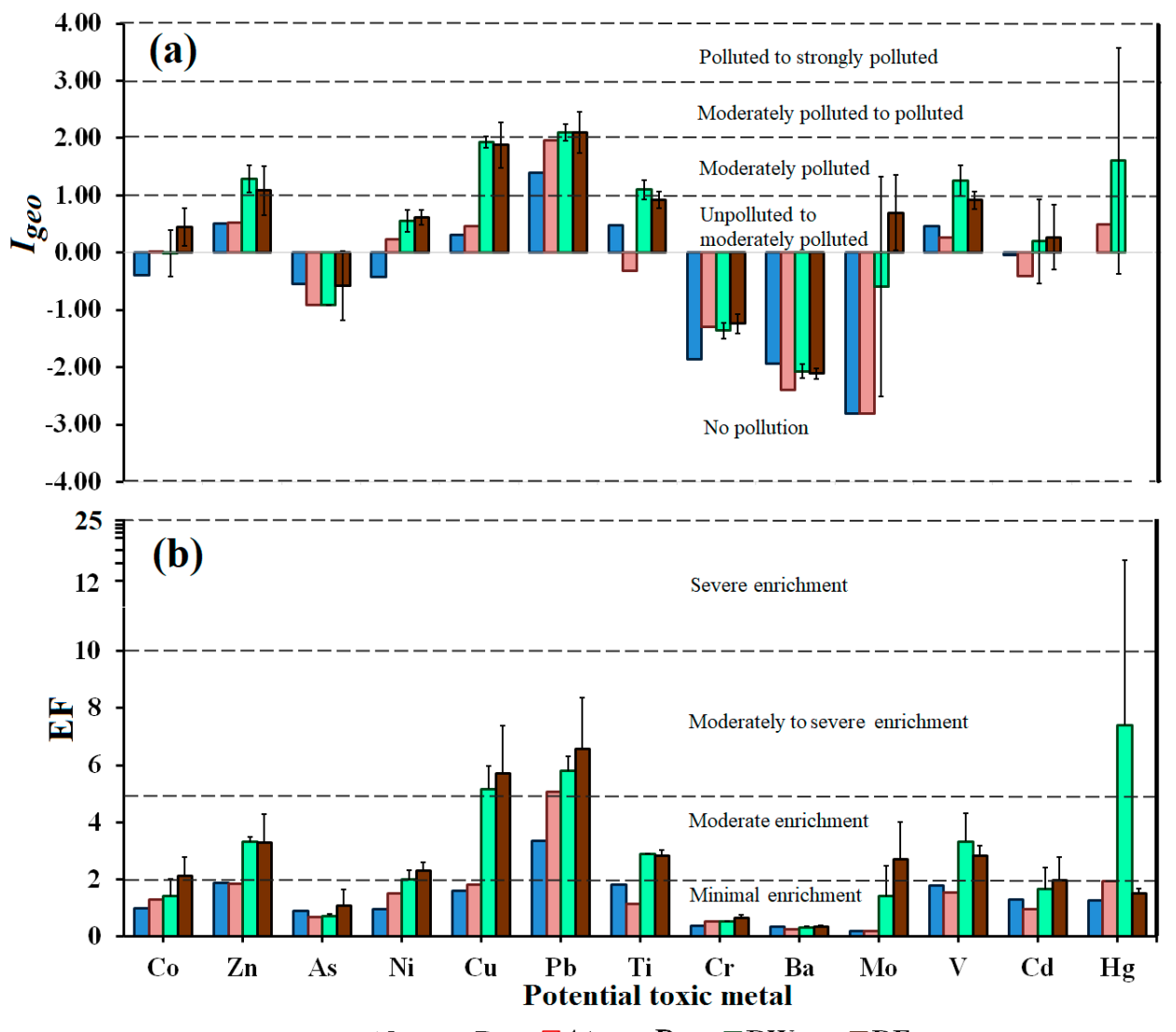

$\square$ Alseseca R. $\quad \square$ Atoyac R. $\quad \square R W \quad \boxminus R F$

(c)

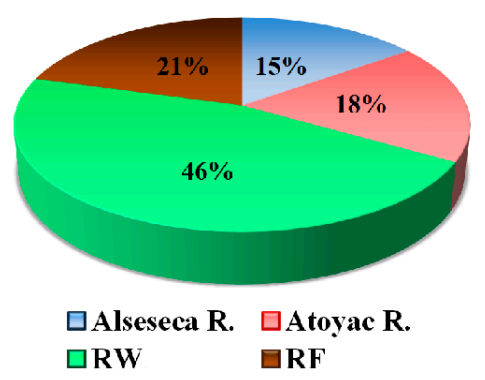

(d)

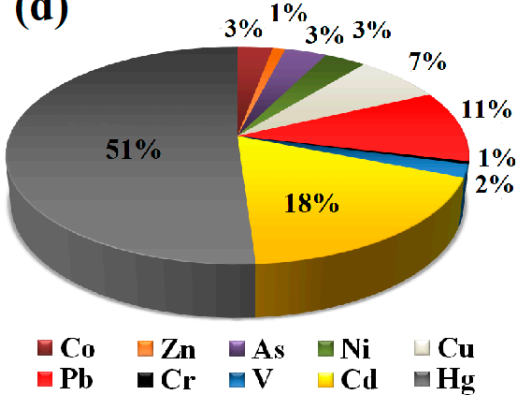

Figure 5. (a) Geoaccumulation Index $\left(I_{g e o}\right)$, (b) Enrichment Factor (EF), (c) Potential ecological risindex (PERI) in all zones studied and (d) Percentage contributed by each metal to PER.

\section{Conclusions}

The present study provides information regarding the content of potential toxic metals $(\mathrm{Co}, \mathrm{Zn}$, $\mathrm{As}, \mathrm{Ni}, \mathrm{Cu}, \mathrm{Pb}, \mathrm{Ti}, \mathrm{Cr}, \mathrm{Ba}, \mathrm{Mo}, \mathrm{V}, \mathrm{Cd}$ and $\mathrm{Hg}$ ) in water, Water hyacinth plants and sediments in a Ramsar site. Results showed that compared to SQuiRTs, the levels of As in Atoyac river and $\mathrm{Hg}$ in Alseseca river are close to the limits, thus posing a potential threat to aquatic life. The results regarding the translocation factors showed that the Water hyacinth plants that prevail in the Ramsar site were efficient accumulators for $\mathrm{Ba}$. In the case of $\mathrm{Co}, \mathrm{Zn}, \mathrm{As}, \mathrm{Ni}, \mathrm{Cu}, \mathrm{Pb}$ and $\mathrm{Cr}$, the Water hyacinth plants acted predominately as indicators of PTMs. The metal content in sediments resembles that of E. crassipes, especially in the roots, suggesting a constant deposition of plants at the bottom of the Reservoir. Different indexes utilized in the present work such as $I_{g e o}$, and EF revealed that sediments in the Ramsar site are moderately contaminated. Mercury is of special concern as according to $I_{\text {geo }}$, and EF, sediments are close to be strongly contaminated by this element. Moreover, PERI showed that $\mathrm{Hg}$ contributes $51 \%$ of the potential ecological risk in the part of the study area where E. crassipes is 
present. The overall results pointed out that the Water hyacinth plants play an important role in the self-depuration process occurring in the Valsequillo reservoir by accumulating PTMs. These results can be used to understand and visualize this type of wetlands as natural systems of self-purification in those sites with the same characteristics.

Future Research: The next stage of the research should include a plan for periodic harvesting of the macrophytes in the Valsequillo reservoir, which allows the biofiltration process to be carried out more efficiently while taking advantage of the biomass in a sustainable manner.

Supplementary Materials: The following are available online at http://www.mdpi.com/2073-4441/11/6/1248/s1, Figure S1: Water hyacinth structure. (a) Stems and leaves, (b) Rhizomes and roots, Table S1. Correlation matrix of physicochemical parameters. Table S2: Uptake of potential toxic metals by Eichhornia crassipes from different types of water treated.

Author Contributions: P.F.R.-E. conceived and directed the project; J.T.-H., A.G.H.-R. performed part of the experiments; J.T.-H. wrote the paper; J.A.M.-P., E.S.-O. and E.M.-T. further improved the concept, structure, contents and writing of the manuscript and also contributed to the discussion.

Funding: This research received no external funding.

Acknowledgments: PFRE, MEPL, JAMP and ESO wishes to thank Instituto Politécnico Nacional (SNI-CONACyT, EDI, and COFAA), México, for their support. The present study was mainly funded by SIP, IPN, Mexico (No. 20162007). THJ and RHAG thanks CONACyT, Mexico, for the research fellowship. Special thanks to Esaú López Martínez.

Conflicts of Interest: The authors declare no conflict of interest. The founding sponsors had no role in the design of the study; in the collection, analyses, or interpretation of data; in the writing of the manuscript, and in the decision to publish the results.

\section{References}

1. Chatterjee, S.; Datta, S.; Mallick, P.H.; Mitra, A.; Vijay Veer, V.; Mukhopadhyay Kumar, S. Use of wetland plants in bioaccumulation of heavy metals. In Plant-Based Remediation Processes; Kumar, D., Ed.; Springer: Berlin/Heidelberg, Germany, 2013; p. 304. ISBN 978-3-642-35563-9.

2. Kamari, A.; Yusof, N.; Abdullah, H.; Haraguchi, A.; Abas, M.F. Assessment of heavy metals in water, sediment, anabas testudineus and eichhornia crassipes in a former mining pond in Perak, Malaysia. Chem. Ecol. 2017, 33, 637-651. [CrossRef]

3. Bradl, H.; Kim, C.; Kramar, U.; Stuben, D. Interaction of heavy metals. In Heavy Metals in the Environment: Origin, Interaction and Remediation; Bradl, H.B., Ed.; Elsevier Academic Press: London, UK, 2005; 269p, ISBN 0-12-088381-3.

4. Romanova, T.E.; Shuvaeva, O.V.; Belchenko, L.A. Phytoextraction of trace elements by water hyacinth in contaminated area of gold mine tailing. Int. J. Phytoremediation 2015, 1549-7879. [CrossRef] [PubMed]

5. Liu, J.; Goyer, R.A.; Waalkes, M.P. Toxic effects of metals. In Casarett and Doull's-Toxicology: The Basic Science of Poisons; Klaassen, C.D., Ed.; McGraw-Hill Medical: New York, NY, USA, 2008; 1309p, ISBN 0071769250.

6. Fabbricino, M.; Ferraro, A.; Luongo, V.; Pontoni, L.; Race, M. Soil washing optimization, recycling of the solution, and ecotoxicity assessment for the remediation of $\mathrm{Pb}$-contaminated sites using EDDS. Sustainability 2018, 10, 636. [CrossRef]

7. Venkatramanan, S.; Chung, S.Y.; Ramkumar, T.; Selvam, S. Ecological risk assessment of selected heavy metals in the surface sediments of three estuaries in the southeastern coast of India. Environ. Earth Sci. 2018, 77, 1-13. [CrossRef]

8. Vu, C.T.; Lin, C.; Shern, C.C.; Yeh, G.; Le, V.G.; Tran, H.T. Contamination, ecological risk and source apportionment of heavy metals in sediments and water of a contaminated river in Taiwan. Ecol. Indic. 2017, 82, 32-42. [CrossRef]

9. Gurung, B.; Race, M.; Fabbricino, M.; Komínková, D.; Libralato, G.; Siciliano, A.; Guida, M. Assessment of metal pollution in the Lambro Creek (Italy). Ecotoxicol. Environ. Saf. 2017, 148, 754-762. [CrossRef]

10. Shruti, V.C.; Rodriguez-Espinosa, P.F.; Escobedo-Urías, D.C.; Martinez-Tavera, E.; Jonathan, M.P. Environmental consequences of metal concentrations in stream sediments of Atoyac river basin, central Mexico: Natural and industrial influences. Int. J. Environ. Chem. Ecol. Geol. Geophys. Eng. 2017, 11, 44-51. 
11. Chai, L.; Li, H.; Yang, Z.; Min, X.; Liao, Q.; Liu, Y.; Men, S.; Yan, Y.; Xu, J. Heavy metals and metalloids in the surface sediments of the Xiangjiang River, Hunan, China: Distribution, contamination, and ecological risk assessment. Environ. Sci. Pollut. Res. 2017, 24, 874-885. [CrossRef]

12. Hakanson, L. An ecological risk index for aquatic pollution control a sedimentological approach. Water Res. 1980, 14, 975-1001. [CrossRef]

13. Müller, G. Index of geoaccumulation in sediments of the Rhine River. Geojournal 1969, 2, 108-118.

14. Rana, V.; Maiti, S.K.; Jagadevan, S. Ecological risk assessment of metals contamination in the sediments of natural urban wetlands in dry tropical climate. Bull. Environ. Contam. Toxicol. 2016, 97, 407-412. [CrossRef] [PubMed]

15. Wojciechowska, E.; Nawrot, N.; Walkusz-Miotk, J.; Matej-Łukowicz, K.; Pazdro, K. Heavy metals in sediments of urban streams: Contamination and health risk assessment of influencing factors. Sustainability 2019, 11, 563. [CrossRef]

16. Agunbiade, F.O.; Olu-Owolabi, B.I.; Adebowale, K.O. Phytoremediation potential of Eichornia crassipes in metal-contaminated coastal water. Bioresour. Technol. 2009, 100, 4521-4526. [CrossRef] [PubMed]

17. Mishra, S.; Maiti, A. The efficiency of Eichhornia crassipes in the removal of organic and inorganic pollutants from wastewater: A review. Environ. Sci. Pollut. Res. 2017, 24, 7921-7937. [CrossRef] [PubMed]

18. Odjegba, V.J.; Fasidi, I.O. Phytoremediation of heavy metals by Eichhornia crassipes. Environmentalist 2007, 27, 349-355. [CrossRef]

19. Vymazal, J. Constructed wetlands for treatment of industrial wastewaters: A review. Ecol. Eng. 2014, 73, 724-751. [CrossRef]

20. Khan, S.; Ahmad, I.; Shah, M.T.; Rehman, S.; Khaliq, A. Use of constructed wetland for the removal of heavy metals from industrial wastewater. J. Environ. Manag. 2009, 90, 3451-3457. [CrossRef]

21. Zhang, D.Q.; Jinadasa, K.B.S.N.; Gersberg, R.M.; Liu, Y.; Tan, S.K.; Ng, W.J. Application of constructed wetlands for wastewater treatment in tropical and subtropical regions (2000-2013). J. Environ. Sci. 2015, 30, 30-46. [CrossRef]

22. Chunkao, K.; Nimpee, C.; Duangmal, K. The King's initiatives using water hyacinth to remove heavy metals and plant nutrients from wastewater through Bueng Makkasan in Bangkok, Thailand. Ecol. Eng. 2012, 39, 40-52. [CrossRef]

23. Li, Z.; Xiao, H.; Cheng, S.; Zhang, L.; Xie, X.; Wu, Z. A comparison on the phytoremediation ability of triazophos by different macrophytes. J. Environ. Sci. 2014, 26, 315-322. [CrossRef]

24. Smolyakov, B.S. Uptake of $\mathrm{Zn}, \mathrm{Cu}, \mathrm{Pb}$, and $\mathrm{Cd}$ by water hyacinth in the initial stage of water system remediation. Appl. Geochem. 2012, 27, 1214-1219. [CrossRef]

25. Melignani, E.; de Cabo, L.I.; Faggi, A.M. Copper uptake by Eichhornia crassipes exposed at high level concentrations. Environ. Sci. Pollut. Res. 2015, 22, 8307-8315. [CrossRef] [PubMed]

26. Upadhyay, A.R.; Tripathi, B.D. Principle and process of biofiltration of $\mathrm{Cd}, \mathrm{Cr}, \mathrm{Co}, \mathrm{Ni} \& \mathrm{~Pb}$ from tropical opencast coalmine effluent. Water Air Soil Pollut. 2007, 180, 213-223.

27. Hadad, H.R.; Maine, M.a.; Mufarrege, M.M.; Del Sastre, M.V.; Di Luca, G.a. Bioaccumulation kinetics and toxic effects of Cr, Ni and Zn on Eichhornia crassipes. J. Hazard. Mater. 2011, 190, 1016-1022. [CrossRef] [PubMed]

28. Newete, S.W.; Erasmus, B.F.N.; Weiersbye, I.M.; Byrne, M.J. Sequestration of precious and pollutant metals in biomass of cultured water hyacinth (Eichhornia crassipes). Environ. Sci. Pollut. Res. 2016, 23, 1-14. [CrossRef] [PubMed]

29. Rodríguez-Espinosa, P.F.; Mendoza-Pérez, J.A.; Tabla-Hernandez, J.; Martínez-Tavera, E.; Monroy-Mendieta, M.M. Biodegradation and kinetics of organic compounds and heavy metals in an artificial wetland system (AWS) by using water hyacinths as a biological filter. Int. J. Phytoremediation 2018, 20, 35-43. [CrossRef] [PubMed]

30. CONAGUA Banco Nacional de Datos de Aguas Superficiales (BANDAS). Available online: http://www.conagua.gob.mx/CONAGUA07/Contenido/Documentos/PortadaBANDAS.htm (accessed on 7 December 2017).

31. Martinez-Tavera, E.; Rodriguez-Espinosa, P.F.; Shruti, V.C.; Sujitha, S.B.; Morales-Garcia, S.S.; Muñoz-Sevilla, N.P. Monitoring the seasonal dynamics of physicochemical parameters from Atoyac River basin (Puebla), Central Mexico: Multivariate approach. Environ. Earth Sci. 2017, 76, 95. [CrossRef] 
32. Rodriguez-Espinosa, P.F.; Morales-García, S.S.; Jonathan, M.P.; Navarrete-Lopez, M.; Bernal-Campos, A.A.; Gonzales-Cesar, A.; Muñoz-Sevilla, N.P. Servicio Ambiental de la Presa Valsequillo para las cuencas de los Ríos del Atoyac-Zahuapan y Alseseca, Puebla, Tlaxcala, México. Inst Nac Ecol Cambio Clim (INECC). Secr Medio Ambient Recur Na 2011, 1-10. Available online: http://viveatoyac.org.mx/images/Biblioteca\%20tem\% C3\%A1tica/Biblioteca\%20sobre\%20el\%20agua/3g010\%20Servicio\%20ambiental\%20de\%20la\%20presa\% 20Valsequillo\%20para\%20las\%20cuencas\%20del\%20Atoyac\%20y\%20Alseseca.pdf (accessed on 7 May 2019).

33. Traversoni, L.; Vélez, H.; Ruiz Martínez, R.; Carreón, E. Manifestación de impacto ambiental: Remoción de lirio acuático en el embalse de Valsequillo. In Semarnat; 2009. Available online: http://sinat.semarnat.gob.mx/ dgiraDocs/documentos/pue/estudios/2009/21PU2009HD056.pdf (accessed on 23 April 2019).

34. Flores-Márquez, E.L.; Jiménez-Suárez, G.; Martínez-Serrano, R.G.; Chávez, R.E.; Pérez, D.S. Study of geothermal water intrusion due to groundwater exploitation in the Puebla Valley aquifer system, Mexico. Hydrogeol. J. 2006, 14, 1216-1230. [CrossRef]

35. Stevens, R.E.; Metcalfe, S.E.; Leng, M.J.; Lamb, A.L.; Sloane, H.J.; Naranjo, E.; González, S. Reconstruction of late Pleistocene climate in the Valsequillo Basin (Central Mexico) through isotopic analysis of terrestrial and freshwater snails. Palaeogeogr. Palaeoclimatol. Palaeoecol. 2012, 319, 16-27. [CrossRef]

36. Urrutia-Fucugauchi, J.; Trigo-Huesca, A.; Téllez-García, E.; Pérez-Cruz, L.; Méndez-Rivero, F. Volcano-sedimentary stratigraphy in the valsequillo basin, central Mexico inferred from electrical resistivity soundings. Geofis. Int. 2014, 53, 87-94. [CrossRef]

37. Wang, Q.; Cui, Y.; Dong, Y. Phytoremediation of polluted waters: Potentials and prospects of wetland plants. Acta Biotechnol. 2002, 22, 199-208. [CrossRef]

38. Branzini, A.; Zubillaga, M.S. Phytostabilization as soil remediation strategy. In Plant-Based Remediation Processes; Dharmendra, K.G., Ed.; Springer: Berlin/Heidelberg, Germany, 2013; 304p, ISBN 978-3-642-35563-9.

39. Meitei, M.D.; Prasad, M.N.V. Bioaccumulation of nutrients and metals in sediment, water, and phoomdi from Loktak Lake (Ramsar site), northeast India: Phytoremediation options and risk assessment. Environ. Monit. Assess. 2016, 188, 329. [CrossRef] [PubMed]

40. Mercado-Borrayo, B.M.; Silke Cram, H.; Rosas Pérez, I.; Hernandez Quiroz, M.; Ponce de Leon Hill, C. Organophosphorus and organochlorine pesticides bioaccumulation by Eichhornia crassipes in irrigation canals in an urban agricultural system. Int. J. Phytoremediation 2015, 17, 701-708. [CrossRef] [PubMed]

41. Baker, A.J.M. Accumulators and excluders-Strategies in the response of plants to heavy metals. J. Plant Nutr. 1981, 3, 643-654. [CrossRef]

42. Reeves, R.D.; Van Der Ent, A.; Baker, A.J.M. Global distribution and ecology of hyperaccumulator plants. In Agromining: Farming for Metals; Van der Ent, A., Echevarria, G., Baker, A.J., Morel, J.L., Eds.; Springer: Cham, Switzerland, 2018; pp. 75-92. ISBN 978-3-319-61898-2.

43. Hseu, Z.Y.; Chen, Z.S.; Tsai, C.C.; Tsui, C.C.; Cheng, S.F.; Liu, C.L.; Lin, H.T. Digestion methods for total heavy metals in sediments and soils. Water Air Soil Pollut. 2002, 141, 189-205. [CrossRef]

44. Jahan, S.; Strezov, V. Comparison of pollution indices for the assessment of heavy metals in the sediments of seaports of NSW, Australia. Mar. Pollut. Bull. 2018, 128, 295-306. [CrossRef] [PubMed]

45. Wang, H.; Wang, J.; Liu, R.; Yu, W.; Shen, Z. Spatial variation, environmental risk and biological hazard assessment of heavy metals in surface sediments of the Yangtze River estuary. Mar. Pollut. Bull. 2015, 93, 250-258. [CrossRef]

46. Mohiuddin, K.M.; Otomo, K.; Ogawa, Y.; Shikazono, N. Seasonal and spatial distribution of trace elements in the water and sediments of the Tsurumi River in Japan. Environ. Monit. Assess. 2012, 184, 265-279. [CrossRef]

47. Kükrer, S.; Seker, S.; Abaci, Z.T.; Kutlu, B. Ecological risk assessment of heavy metals in surface sediments of northern littoral zone of Lake Çildir, Ardahan, Turkey. Environ. Monit. Assess. 2014, 186, 3847-3857. [CrossRef]

48. Mamat, Z.; Haximu, S.; Zhang, Z.Y.; Aji, R. An ecological risk assessment of heavy metal contamination in the surface sediments of Bosten Lake, northwest China. Environ. Sci. Pollut. Res. 2016, 23, 7255-7265. [CrossRef]

49. Kusin, F.M.; Rahman, M.S.A.; Madzin, Z.; Jusop, S.; Mohamat-Yusuff, F.; Ariffin, M.; Mohd Syakirin Md, Z. The occurrence and potential ecological risk assessment of bauxite mine-impacted water and sediments in Kuantan, Pahang, Malaysia. Environ. Sci. Pollut. Res. 2017, 24, 1306-1321. [CrossRef] [PubMed]

50. Ali, A.E.; Strezov, V.; Davies, P.J.; Wright, I. River sediment quality assessment using sediment quality indices for the Sydney basin, Australia affected by coal and coal seam gas mining. Sci. Total Environ. 2018, 616, 695-702. [CrossRef] [PubMed] 
51. Wang, N.; Wang, A.; Kong, L.; He, M. Calculation and application of Sb toxicity coefficient for potential ecological risk assessment. Sci. Total Environ. 2018, 610, 167-174. [CrossRef] [PubMed]

52. Gárfias, J.; Arroyo, N.; Aravena, R. Hydrochemistry and origins of mineralized waters in the Puebla aquifer system, Mexico. Environ. Earth Sci. 2009, 59, 1789-1805. [CrossRef]

53. Jackson, L.J. Paradigms of metal accumulation in rooted aquatic vascular plants. Sci. Total Environ. 1998, 7, 223-231. [CrossRef]

54. Pinto, A.P.; de Varennes, A.; Lopes, E.M.; Teixeira, D.M. Biological approaches for remediation of metal contaminated sites. In Phytoremediation Management of Environmental Contaminants; Ansari, A.A., Gill, S.S., Gill, R., Lanza, G.R., Newman, L., Eds.; Springer International Publishing: Cham, Switzerland, 2016; Volume 3, p. 582. ISBN 978-3-319-40146-1.

55. Ali, H.; Khan, E.; Sajad, M.A. Phytoremediation of heavy metals-Concepts and applications. Chemosphere 2013, 91, 869-881. [CrossRef] [PubMed]

56. Dantas-Santos, N.; Gomes, D.L.; Costa, L.S.; Cordeiro, S.L.; Costa, M.S.S.P.; Trindade, E.S.; Franco, C.R.C.; Scortecci, K.C.; Leite, E.L.; Rocha, H.A.O. Freshwater plants synthesize sulfated polysaccharides: Heterogalactans from water hyacinth (Eicchornia crassipes). Int. J. Mol. Sci. 2012, 13, 961-976. [CrossRef] [PubMed]

57. Tejeda, S.; Zarazúa, G.; Ávila-Pérez, P.; Carapia-Morales, L.; Martínez, T. Total reflection X-ray fluorescence spectrometric determination of elements in water hyacinth from the Lerma River. Spectrochim. Acta Part B 2010, 65, 483-488. [CrossRef]

58. Upadhyay, A.R.; Mishra, V.K.; Pandey, S.K.; Tripathi, B.D. Biofiltration of secondary treated municipal wastewater in a tropical city. Ecol. Eng. 2007, 30, 9-15. [CrossRef]

59. Bonanno, G.; Borg, J.A.; Di Martino, V. Levels of heavy metals in wetland and marine vascular plants and their biomonitoring potential: A comparative assessment. Sci. Total Environ. 2017, 576, 796-806. [CrossRef]

60. Aurangzed, N.; Nisa, S.; Bibi, Y.; Javed, F.; Hussain, F. Phytoremediation potential of aquatic herbs from steel foundry effluent. Braz. J. Chem. Eng. 2014, 31, 881-886. [CrossRef]

61. Larocque, A.C.L.; Stimac, J.A.; Siebe, C.; Greengrass, K.; Chapman, R.; Mejia, S.R. Deposition of a high-sulfidation Au assemblage from a magmatic volatile phase, Volcán Popocatépetl, Mexico. J. Volcanol. Geotherm. Res. 2008, 170, 51-60. [CrossRef]

62. Deng, H.; Zhang, J.; Chen, S.; Yang, L.; Wang, D.; Yu, S. Metal release/accumulation during the decomposition of potamogeton crispus in a shallow macrophytic lake. J. Environ. Sci. 2016, 42, 71-78. [CrossRef] [PubMed]

63. Kumari, M.; Tripathi, B.D. Effect of aeration and mixed culture of Eichhornia crassipes and Salvinia natans on removal of wastewater pollutants. Ecol. Eng. 2014, 62, 48-53. [CrossRef]

64. Zimmels, Y.; Kirzhner, F.; Kadmon, A. Effect of circulation and aeration on wastewater treatment by floating aquatic plants. Sep. Purif. Technol. 2009, 66, 570-577. [CrossRef]

65. Chatterjee, S.; Mitra, A.; Datta, S.; Veer, V. Phytoremediation protocols: An overview. In Plant-Based Remediation Processes; Dharmendra, K.G., Ed.; Springer: Berlin/Heidelberg, Germany, 2013; 304p, ISBN 978-3-642-35563-9.

66. Pellegrini, E.; Petranich, E.; Acquavita, A.; Canário, J.; Emili, A.; Covelli, S. Mercury uptake by halophytes in response to a long-term contamination in coastal wetland salt marshes (northern Adriatic Sea). Environ. Geochem. Health 2017, 39, 1-17. [CrossRef]

67. Wu, X.; Yu, J.; Qiu, H.; Fang, H. Pollution and ecological risk assessment of nutrients associated with deposited sediments collected from roof and road surfaces. Environ. Sci. Pollut. Res. 2018, 25, 8943-8950. [CrossRef]

(C) 2019 by the authors. Licensee MDPI, Basel, Switzerland. This article is an open access article distributed under the terms and conditions of the Creative Commons Attribution (CC BY) license (http://creativecommons.org/licenses/by/4.0/). 